\title{
Evidence on Digital Mental Health Interventions for Adolescents and Young People: Systematic Overview
}

Susanna Lehtimaki ${ }^{1^{*}}$, MPH, MSSc; Jana Martic ${ }^{1}$, MSc; Brian Wahl ${ }^{1,2}$, MPH, PhD; Katherine T Foster ${ }^{3,4}$, PhD; Nina Schwalbe $e^{1,5,6^{*}}, \mathrm{MPH}$

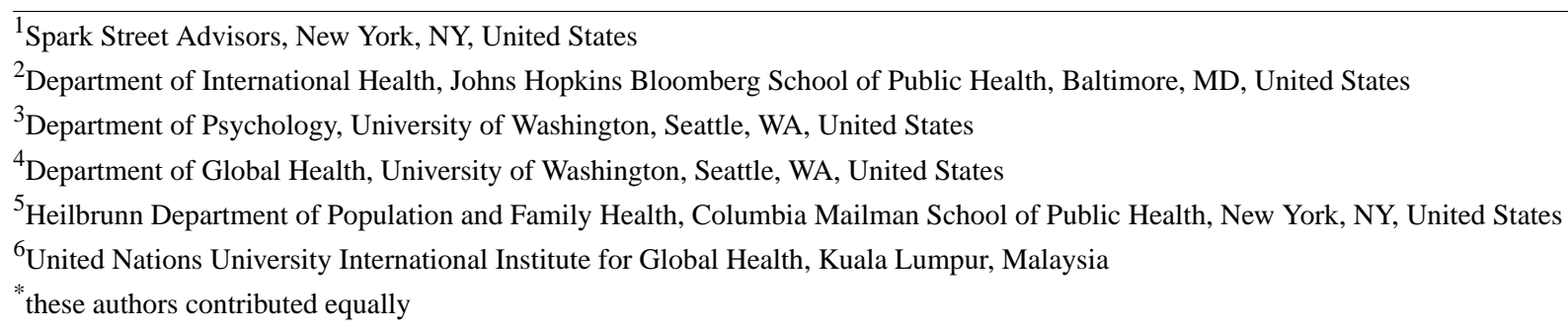

Corresponding Author:

Nina Schwalbe, MPH

Heilbrunn Department of Population and Family Health

Columbia Mailman School of Public Health

722 W 168th Street

New York, NY, 10032

United States

Phone: 19172262645

Email: nschwalbe@ssc.nyc

\section{Abstract}

Background: An estimated 1 in 5 adolescents experience a mental health disorder each year; yet because of barriers to accessing and seeking care, most remain undiagnosed and untreated. Furthermore, the early emergence of psychopathology contributes to a lifelong course of challenges across a broad set of functional domains, so addressing this early in the life course is essential. With increasing digital connectivity, including in low- and middle-income countries, digital health technologies are considered promising for addressing mental health among adolescents and young people. In recent years, a growing number of digital health interventions, including more than 2 million web-based mental health apps, have been developed to address a range of mental health issues.

Objective: This review aims to synthesize the current evidence on digital health interventions targeting adolescents and young people with mental health conditions, aged between 10-24 years, with a focus on effectiveness, cost-effectiveness, and generalizability to low-resource settings (eg, low- and middle-income countries).

Methods: We searched MEDLINE, PubMed, PsycINFO, and Cochrane databases between January 2010 and June 2020 for systematic reviews and meta-analyses on digital mental health interventions targeting adolescents and young people aged between 10-24 years. Two authors independently screened the studies, extracted data, and assessed the quality of the reviews.

Results: In this systematic overview, we included 18 systematic reviews and meta-analyses. We found evidence on the effectiveness of computerized cognitive behavioral therapy on anxiety and depression, whereas the effectiveness of other digital mental health interventions remains inconclusive. Interventions with an in-person element with a professional, peer, or parent were associated with greater effectiveness, adherence, and lower dropout than fully automatized or self-administered interventions. Despite the proposed utility of digital interventions for increasing accessibility of treatment across settings, no study has reported sample-specific metrics of social context (eg, socioeconomic background) or focused on low-resource settings.

Conclusions: Although digital interventions for mental health can be effective for both supplementing and supplanting traditional mental health treatment, only a small proportion of existing digital platforms are evidence based. Furthermore, their cost-effectiveness and effectiveness, including in low- and middle-income countries, have been understudied. Widespread adoption and scale-up of digital mental health interventions, especially in settings with limited resources for health, will require more rigorous and consistent demonstrations of effectiveness and cost-effectiveness vis-à-vis the type of service provided, target population, and the current standard of care. 
(JMIR Ment Health 2021;8(4):e25847) doi: 10.2196/25847

\section{KEYWORDS}

digital health; adolescent health; young people; mental health; digital technologies

\section{Introduction}

\section{Background}

Mental health issues remain underdiagnosed and undertreated among adolescents and young people (aged 10-24 years) [1]. Ignored by many health and social services and policies worldwide [2], adolescents and young people are particularly vulnerable to many conditions affecting mental health. Nearly $50 \%$ of mental health disorders begin by the age of 14 years, and $75 \%$ of mental health disorders begin by the age of 24 years [3]; an estimated 1 in 5 adolescents experience a mental health disorder each year [4]. The emergence of symptom sequelae, even below the diagnostic threshold, signals an increased vulnerability to life course-persistent mental health problems and consequences if not addressed early. Among men and women aged between 15-19 years, suicide, which is more common among young people than adults [5], is one of the top 3 causes of death worldwide, and depression is among the leading causes of disability for those aged between 10-19 years [6].

At the same time, young people are growing up in the digital world and accessing the internet at increasingly younger ages [7]. As the most connected age group in the population, more than $70 \%$ of young people aged between 15-24 years are "online" [8]. Although there are income-based and geographical disparities in digital access, $43 \%$ of people in low- and middle-income countries use the internet, and even in low-income countries, $72 \%$ of people have access to mobile phones, and $16 \%$ of people have access to the internet [9].

Although there are clearly some negative effects of technology on this age group, including behavioral addiction, cyber-bullying, depression, sexual exploitation, and abuse [10-12], the use of digitally enabled technology is considered a promising platform for preventing morbidity and enhancing well-being and quality of life [13]. Critically, digital technologies may offer especially critical support for adolescents and young people in low-resource settings where barriers to care may be numerous and insurmountable.

Given the increasing number of adolescents and young people using digital technologies, digital mental health interventions are considered to have the specific potential to support mental health and well-being in this group [14,15]. Specifically, digital technology could provide opportunities to access mental health services and information while also increasing patient empowerment, participation [16], and help-seeking and helping to overcome the stigma that is often linked to mental health services [17]. With more than 2 million mental health apps already available, including 40,000 classified as medical [18], the demand for this innovation is evident. However, the plethora of these apps may have outpaced the development of a correspondingly large evidence base on their effectiveness.

\section{Objectives}

A number of systematic reviews and meta-analyses have been conducted over the past 10 years on the use of digital technology to enhance mental health among adolescents and young people. A higher-level synthesis of information across these meta-analyses and reviews is needed to identify whether there is converging evidence for their effectiveness and to assess systematic issues with research in this area. Consequently, this systematic overview provides a high-level synthesis of the current evidence on the effectiveness of digital health interventions targeting adolescents and young people (ie, aged 10-24 years as defined by the World Health Organization and others [19,20]; Textbox 1) with diagnosed or self-reported mental health conditions, including affective, behavioral, and trauma-related conditions (eg, anxiety, depression, psychological distress, eating disorders, and posttraumatic stress disorder). Furthermore, it aims to characterize the factors, including digital platforms and design elements used, that contribute to the effectiveness. Finally, it aims to describe the extent to which there is evidence of the economic benefits of such interventions and determine the extent to which previous research in this area may generalize to low-resource settings, including low- and middle-income countries.

The research questions are as follows:

- In adolescents and young people aged between 10 and 24 years, to what extent are digital health interventions effective in addressing mental health conditions, compared with standard face-to-face treatment, placebo, or no treatment?

- What factors contribute to effectiveness (ie, what makes effective interventions effective)?

- To what extent is there evidence on cost-effectiveness?

- To what extent are the findings generalizable to adolescents and young people from a range of settings, including lowand middle-income countries? 
Textbox 1. Definitions of key terms.

Adolescents and young people

- According to the World Health Organization, adolescents are individuals aged 10-19 years, and young people are individuals aged 10-24 years [19]

Mental health conditions, mental disorders

- Mental health problems with different symptoms, characterized by a combination of abnormal thoughts, perceptions, emotions, behavior, and relationships with others [21,22]

Digital mental health intervention

- Information, support, and therapy for mental health conditions delivered through an electronic medium with the aim of treating, alleviating, or managing symptoms $[23,24]$

Cognitive behavioral therapy (CBT), computerized CBT (cCBT)

- A form of psychological treatment to identify maladaptive patterns of thinking, emotional response, or behavior and substituting them with desirable patterns [25]. cCBT refers to computerized implementation of CBT

Effectiveness, effect

- The ability of an intervention to produce intended outcomes, estimated by comparing the intervention with no intervention (ie, better than nonactive control) and/or an existing evidence-based intervention (ie, no difference from active control) [26]

Active control

- A comparison group receiving standard treatment, including face-to-face therapy, alternative therapy, or materials [26]

Nonactive control

- A comparison group not receiving or performing any activity. These may include placebo treatment, no treatment, or assigned to a waitlist to receive intervention after completion of the trial [26]

\section{Methods}

\section{Search Strategy and Selection Criteria}

The review was conducted using a predefined protocol. We conducted an electronic review of the literature from the MEDLINE, PubMed, PsycINFO, and Cochrane databases. The review was limited to peer-reviewed articles published in English between January 1, 2011, and July 6, 2020. We used a combination of keywords: ("digital," "mHealth," "eHealth," "web-based," "internet-based," "mobile phone," "text message," "SMS," "artificial intelligence") AND ("adolescen*," "youth," "young," "child," "student") AND ("mental health," "wellbeing"). Our search was limited to overview types of studies, such as meta-analyses and systematic reviews.

Identified references were screened independently by 2 reviewers (SL and JM) by conducting an abstract and title search with the following inclusion criteria, following a predefined PICOS (Population, Intervention, Comparator, Outcome, Setting) framework:

- Population: Adolescents and young people, defined as primarily aged between 10 and 24 years (or if older participants were included, the mean age was $<25$ years), with a mental health condition, including anxiety, affective, and behavioral conditions (diagnosed and self-reported)

- Intervention: Consumer-facing, partially or fully self-administered, mental health intervention delivered through a digital platform (eg, web-based, computer, or mobile phone)
- Comparator: Active (ie, standard nondigital care and alternative materials) or passive control (ie, placebo and no treatment)

- Outcome: Mental health improvement as reported by studies (ie, diagnosed or self-reported mental health conditions, including affective, behavioral, and trauma-related conditions)

- Setting: Nonclinical, nonfacility-based setting in any country

Potentially relevant studies identified through the screening process were assessed independently for final inclusion by 2 reviewers (SL and JM) after being acquired in full text. References were excluded if they were not exclusive to this age group; were delivered at the health care facility (eg, telemedicine by clinicians); targeted adolescents and young people with chronic diseases, such as HIV, diabetes, or cancer; targeted adolescents and young people with mental and behavioral disorders because of psychoactive substance use; or were primarily addressing parenting skills or targeting parents. Study protocols and nonpeer-reviewed papers were excluded.

\section{Data Extraction and Quality Assessment}

In total, 2 reviewers (SL and JM) independently extracted information from the studies, building a matrix including data on participants (age and other available background characteristics), interventions, mental health issues addressed, setting (eg, delivery platforms and countries), and key findings in terms of clinical effectiveness. The reviewers also assessed the quality of the articles by using the AMSTAR 2 (A 
Measurement Tool to Assess Systematic Reviews) [27] tool, which is a validated tool to analyze the quality of systematic reviews and meta-analyses with ratings from high to critically low. The guidance document of the tool [27] was thoroughly followed. Any disagreement in either of these actions was resolved through discussion.

\section{Data Synthesis}

We synthesized evidence from the articles describing the effectiveness of digital mental health interventions against clinical outcomes, therapy used, and digital platform deployed as well as reviewed factors associated with effectiveness, sustainability of outcomes, completion, and adherence. Finally, we reviewed and synthesized the extent to which there was evidence on the cost-effectiveness and the potential generalizability of the findings to low- and middle-income countries. Given the high heterogeneity of the studies, we did not conduct a statistical analysis.

\section{Results}

\section{Overview}

The initial search yielded 1295 articles. After excluding duplicate references, the number of articles was reduced to 1098. The search strategy was complemented by a manual search of reference lists of key articles, which yielded an additional 8 articles for eligibility assessment (Figure 1).

After title screening, we conducted full-text appraisal and excluded articles that did not meet the inclusion criteria. A total of 18 articles were finally included (Table 1).

Figure 1. PRISMA (Preferred Reporting Items for Systematic Reviews and Meta-Analyses) flowchart.

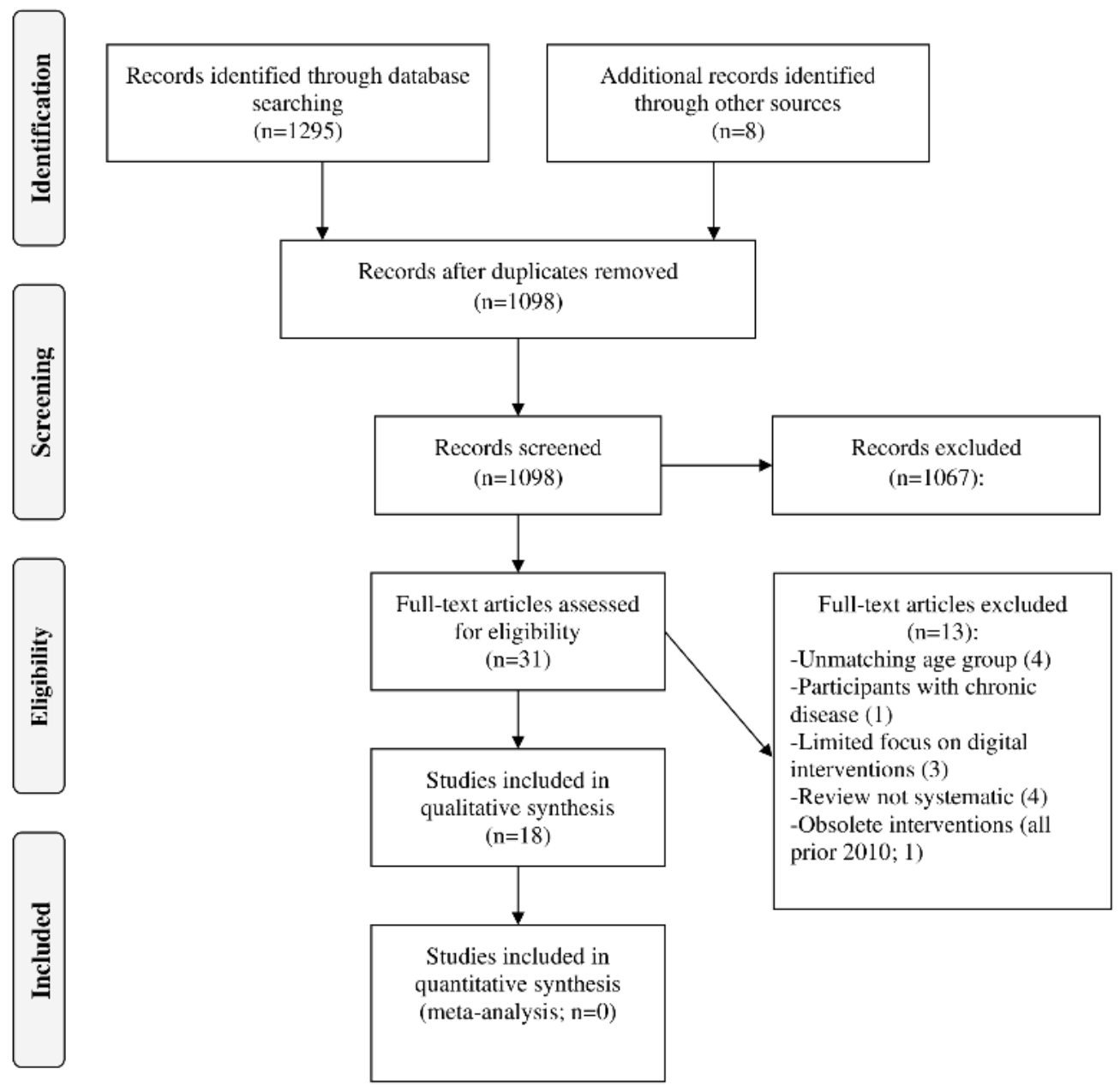


Table 1. Study characteristics.

\begin{tabular}{|c|c|c|c|c|c|c|c|}
\hline Author & Primary studies & $\begin{array}{l}\text { Intervention, digi- } \\
\text { tal platform }\end{array}$ & Outcome & $\begin{array}{l}\text { Comparison interven- } \\
\text { tions }\end{array}$ & $\begin{array}{l}\text { Total } \\
\text { sample }\end{array}$ & $\begin{array}{l}\text { Participants age } \\
\text { (range and mean, } \\
\text { if available) }\end{array}$ & $\begin{array}{l}\text { Geographical } \\
\text { coverage }\end{array}$ \\
\hline $\begin{array}{l}\text { Barnes et al } \\
(2018)[28]\end{array}$ & $\begin{array}{l}\text { Systematic re- } \\
\text { view of } 2 \mathrm{RCTs}^{\mathrm{a}} \\
\text { and } 3 \mathrm{NRSs}^{\mathrm{b}} \text { on } \\
3 \text { games }\end{array}$ & Video games & Anxiety & $\begin{array}{l}\text { Nonactive (alternative } \\
\text { nontherapeutic video } \\
\text { game) }\end{array}$ & 410 & Up to 19 years & $\begin{array}{l}\text { China, Hong } \\
\text { Kong, the } \\
\text { Netherlands, and } \\
\text { the United King- } \\
\text { dom }\end{array}$ \\
\hline $\begin{array}{l}\text { Bry et al } \\
(2018) \text { [29] }\end{array}$ & $\begin{array}{l}\text { Systematic re- } \\
\text { view and content } \\
\text { analysis of } 121 \\
\text { apps }\end{array}$ & Mobile apps & Anxiety & No control group & $\begin{array}{l}\text { Not re- } \\
\text { ported }\end{array}$ & $\begin{array}{l}\text { Not defined (chil- } \\
\text { dren and adoles- } \\
\text { cents) }\end{array}$ & Not defined \\
\hline $\begin{array}{l}\text { Grist et al } \\
\text { (2017) [30] }\end{array}$ & $\begin{array}{l}\text { Systematic re- } \\
\text { view of } 23 \\
\text { NRTs }^{\mathrm{c}} \text { and } 1 \\
\text { RCT on } 15 \text { apps }\end{array}$ & Mobile apps & $\begin{array}{l}\text { Mental health, } \\
\text { well-being, anxi- } \\
\text { ety, depression, } \\
\text { suicide, obsessive- } \\
\text { compulsive disor- } \\
\text { der, and eating dis- } \\
\text { orders }\end{array}$ & $\begin{array}{l}\text { Active (nondigital in- } \\
\text { tervention; nb. Only } \\
\text { one RCT included in } \\
\text { the review) }\end{array}$ & 1054 & Up to 18 years & $\begin{array}{l}\text { Australia, Cana- } \\
\text { da, Denmark, Ire- } \\
\text { land, the Nether- } \\
\text { lands, and the } \\
\text { United States }\end{array}$ \\
\hline $\begin{array}{l}\text { Hollis et al } \\
\text { (2017) [24] }\end{array}$ & $\begin{array}{l}\text { Systematic re- } \\
\text { view of } 30 \text { RCTs; } \\
\text { meta-review of } \\
21 \text { articles on } 147 \\
\text { interventions }\end{array}$ & $\begin{array}{l}\text { Internet-based in- } \\
\text { terventions, mo- } \\
\text { bile apps, and } \\
\text { eHealth }\end{array}$ & $\begin{array}{l}\text { Anxiety, depres- } \\
\text { sion, attention } \\
\text { deficit hyperactivi- } \\
\text { ty disorder, autism } \\
\text { spectrum disorder, } \\
\text { psychosis, eating } \\
\text { disorders, and } \\
\text { posttraumatic } \\
\text { stress disorder }\end{array}$ & $\begin{array}{l}\text { Mixed nonactive } \\
\text { (waitlist, no interven- } \\
\text { tion) and active (atten- } \\
\text { tion control group, } \\
\text { limited intervention) }\end{array}$ & 5333 & Up to 25 years & $\begin{array}{l}\text { Australia, China, } \\
\text { the Netherlands, } \\
\text { New Zealand, } \\
\text { Norway, Israel, } \\
\text { Sweden, Switzer- } \\
\text { land, the United } \\
\text { Kingdom, and the } \\
\text { United States }\end{array}$ \\
\hline $\begin{array}{l}\text { Davies et al } \\
\text { (2014) [31] }\end{array}$ & $\begin{array}{l}\text { Systematic re- } \\
\text { view of } 17 \text { RCTs } \\
\text { and meta-analysis } \\
\text { of } 14 \text { RCTs }\end{array}$ & $\begin{array}{l}\text { Computer-deliv- } \\
\text { ered or web- } \\
\text { based interven- } \\
\text { tions }\end{array}$ & $\begin{array}{l}\text { Anxiety, depres- } \\
\text { sion, psychological } \\
\text { distress, and stress }\end{array}$ & $\begin{array}{l}\text { Mixed nonactive (no } \\
\text { treatment, waitlist) } \\
\text { and active (alternative } \\
\text { materials) }\end{array}$ & 1480 & $\begin{array}{l}17-51 \text { years; mean } \\
22.6 \text { years }\end{array}$ & $\begin{array}{l}\text { Australia, Cana- } \\
\text { da, Norway, } \\
\text { Spain, the United } \\
\text { Kingdom, and the } \\
\text { United States }\end{array}$ \\
\hline $\begin{array}{l}\text { Farrer et al } \\
\text { (2013) [32] }\end{array}$ & $\begin{array}{l}\text { Systematic re- } \\
\text { view of } 26 \text { RCTs } \\
\text { and } 1 \text { randomized } \\
\text { trial }\end{array}$ & $\begin{array}{l}\text { Internet-based, } \\
\text { audio, virtual real- } \\
\text { ity, and computer } \\
\text { programs }\end{array}$ & $\begin{array}{l}\text { Anxiety and depres- } \\
\text { sion }\end{array}$ & $\begin{array}{l}\text { Mixed nonactive (no } \\
\text { intervention, waitlist) } \\
\text { and active (attention } \\
\text { control group) }\end{array}$ & $\begin{array}{l}\text { Not re- } \\
\text { ported }\end{array}$ & $18-25$ years & $\begin{array}{l}\text { Australia, Bel- } \\
\text { gium, China, } \\
\text { Italy, the Nether- } \\
\text { lands, Spain, the } \\
\text { United Kingdom, } \\
\text { and the United } \\
\text { States }\end{array}$ \\
\hline $\begin{array}{l}\text { Valimaki et } \\
\text { al (2017) } \\
{[33]}\end{array}$ & $\begin{array}{l}\text { Systematic re- } \\
\text { view of } 22 \text { RCTs } \\
\text { and meta-analysis } \\
\text { of } 15 \text { RCTs }\end{array}$ & $\begin{array}{l}\text { Internet-based in- } \\
\text { terventions }\end{array}$ & $\begin{array}{l}\text { Depression, anxi- } \\
\text { ety, and stress }\end{array}$ & $\begin{array}{l}\text { Mixed nonactive and } \\
\text { active (not specified) }\end{array}$ & 4979 & $10-24$ years & $\begin{array}{l}\text { Australia, Cana- } \\
\text { da, China, the } \\
\text { Netherlands, } \\
\text { New Zealand, } \\
\text { Norway, the } \\
\text { United Kingdom, } \\
\text { and the United } \\
\text { States }\end{array}$ \\
\hline $\begin{array}{l}\text { Harrer et al } \\
\text { (2019) [34] }\end{array}$ & $\begin{array}{l}\text { Systematic re- } \\
\text { view of } 48 \text { ran- } \\
\text { domized trials }\end{array}$ & $\begin{array}{l}\text { Internet-based } \\
\text { psychological in- } \\
\text { terventions }\end{array}$ & $\begin{array}{l}\text { Anxiety, depres- } \\
\text { sion, stress, sleep } \\
\text { problems, eating } \\
\text { disorders, and } \\
\text { well - being }\end{array}$ & $\begin{array}{l}\text { Mixed nonactive } \\
\text { (waitlist, placebo) and } \\
\text { active (diaries, recom- } \\
\text { mendations for behav- } \\
\text { ior change) }\end{array}$ & 10,583 & $\begin{array}{l}\text { Up to } 29 \text { years; } \\
\text { mean } 22 \text { years }\end{array}$ & $\begin{array}{l}\text { Australia, Cana- } \\
\text { da, Finland, Ger- } \\
\text { many, Ireland, } \\
\text { Norway, Roma- } \\
\text { nia, Spain, Swe- } \\
\text { den, the United } \\
\text { Kingdom, and the } \\
\text { United States }\end{array}$ \\
\hline
\end{tabular}




\begin{tabular}{|c|c|c|c|c|c|c|c|}
\hline Author & Primary studies & $\begin{array}{l}\text { Intervention, digi- } \\
\text { tal platform }\end{array}$ & Outcome & $\begin{array}{l}\text { Comparison interven- } \\
\text { tions }\end{array}$ & $\begin{array}{l}\text { Total } \\
\text { sample }\end{array}$ & $\begin{array}{l}\text { Participants age } \\
\text { (range and mean, } \\
\text { if available) }\end{array}$ & $\begin{array}{l}\text { Geographical } \\
\text { coverage }\end{array}$ \\
\hline $\begin{array}{l}\text { Garrido et al } \\
(2019)[35]\end{array}$ & $\begin{array}{l}\text { Systematic re- } \\
\text { view of } 27 \text { RCTs } \\
\text { and } 13 \text { NRTs on } \\
32 \text { interventions } \\
\text { and meta-analysis } \\
\text { of } 15 \text { RCTs }\end{array}$ & $\begin{array}{l}\text { Computer, web- } \\
\text { based, and smart- } \\
\text { phone-delivered } \\
\text { intervention }\end{array}$ & $\begin{array}{l}\text { Anxiety and depres- } \\
\text { sion }\end{array}$ & $\begin{array}{l}\text { Mixed nonactive } \\
\text { (waitlist) and active } \\
\text { (alternative therapeu- } \\
\text { tic intervention) }\end{array}$ & 16,874 & $12-25$ years & $\begin{array}{l}\text { Australia, Cana- } \\
\text { da, Chile, China, } \\
\text { Hong Kong, Ire- } \\
\text { land, Japan, New } \\
\text { Zealand, North- } \\
\text { ern Europe, the } \\
\text { United Kingdom, } \\
\text { and the United } \\
\text { States }\end{array}$ \\
\hline $\begin{array}{l}\text { Pretorius et } \\
\text { al (2019) } \\
{[36]}\end{array}$ & $\begin{array}{l}\text { Systematic re- } \\
\text { view of } 27 \text { quali- } \\
\text { tative, feasibility, } \\
\text { and comparative } \\
\text { studies and } 1 \\
\text { RCT }\end{array}$ & $\begin{array}{l}\text { Web-based help- } \\
\text { seeking interven- } \\
\text { tions }\end{array}$ & $\begin{array}{l}\text { Psychological dis- } \\
\text { tress }\end{array}$ & No control group & $\begin{array}{l}\text { Not re- } \\
\text { ported }\end{array}$ & $12-25$ years & $\begin{array}{l}\text { Australia, Cana- } \\
\text { da, Ireland, the } \\
\text { Netherlands, the } \\
\text { United Kingdom, } \\
\text { and the United } \\
\text { States }\end{array}$ \\
\hline $\begin{array}{l}\text { Ridout et al } \\
(2018)[37]\end{array}$ & $\begin{array}{l}\text { Systematic re- } \\
\text { view of } 9 \text { descrip- } \\
\text { tive studies on } 5 \\
\text { interventions }\end{array}$ & $\begin{array}{l}\text { Social network- } \\
\text { ing sites }\end{array}$ & $\begin{array}{l}\text { Depression, psy- } \\
\text { chosis, health liter- } \\
\text { acy, social support, } \\
\text { and general well- } \\
\text { being }\end{array}$ & No control group & $\begin{array}{l}\text { Not re- } \\
\text { ported }\end{array}$ & Up to 25 years & $\begin{array}{l}\text { Australia, China, } \\
\text { Hong Kong, and } \\
\text { the United States }\end{array}$ \\
\hline $\begin{array}{l}\text { Podina et al } \\
(2016)[38]\end{array}$ & $\begin{array}{l}\text { Meta-analysis of } \\
8 \text { RCTs }\end{array}$ & $\mathrm{cCBT}^{\mathrm{d}}$ & Anxiety & 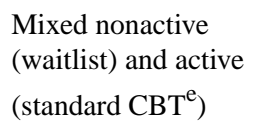 & 404 & $7-18$ years & $\begin{array}{l}\text { Australia, Cana- } \\
\text { da, Spain, and the } \\
\text { United States }\end{array}$ \\
\hline $\begin{array}{l}\text { Ebert et al } \\
(2015) \text { [39] }\end{array}$ & $\begin{array}{l}\text { Meta-analysis of } \\
13 \text { RCTs }\end{array}$ & $\mathrm{cCBT}$ & $\begin{array}{l}\text { Anxiety and depres- } \\
\text { sion }\end{array}$ & $\begin{array}{l}\text { Nonactive (no treat- } \\
\text { ment, placebo) }\end{array}$ & 796 & Up to 25 years & $\begin{array}{l}\text { Australia, the } \\
\text { Netherlands, } \\
\text { New Zealand, } \\
\text { Sweden, the } \\
\text { United Kingdom, } \\
\text { and the United } \\
\text { States }\end{array}$ \\
\hline $\begin{array}{l}\text { Pennant et al } \\
(2015)[40]\end{array}$ & $\begin{array}{l}\text { Systematic re- } \\
\text { view and meta- } \\
\text { analysis of } 27 \\
\text { RCTs }\end{array}$ & cCBT & $\begin{array}{l}\text { Anxiety and depres- } \\
\text { sion }\end{array}$ & $\begin{array}{l}\text { Mixed nonactive } \\
\text { (waitlist, placebo, no } \\
\text { intervention) and ac- } \\
\text { tive (standard CBT) }\end{array}$ & 3389 & 5-25 years & $\begin{array}{l}\text { Australia, China, } \\
\text { the Netherlands, } \\
\text { New Zealand, Is- } \\
\text { rael, Sweden, the } \\
\text { United Kingdom, } \\
\text { and the United } \\
\text { States }\end{array}$ \\
\hline $\begin{array}{l}\text { Ye et al } \\
(2014)[41]\end{array}$ & $\begin{array}{l}\text { Meta-analysis of } \\
7 \text { RCTs }\end{array}$ & cCBT and SMS & $\begin{array}{l}\text { Anxiety and depres- } \\
\text { sion }\end{array}$ & $\begin{array}{l}\text { Mixed nonactive } \\
\text { (waitlist) and active } \\
\text { (standard CBT, alter- } \\
\text { native intervention) }\end{array}$ & 569 & 7- 25 years & $\begin{array}{l}\text { Australia and the } \\
\text { United States }\end{array}$ \\
\hline $\begin{array}{l}\text { Grist et al } \\
(2019)[42]\end{array}$ & $\begin{array}{l}\text { Meta-analysis of } \\
34 \text { RCTs on } 29 \\
\text { interventions }\end{array}$ & $\begin{array}{l}\text { cCBT, computer- } \\
\text { delivered atten- } \\
\text { tion, or cognitive } \\
\text { bias modification } \\
\text { programs }\end{array}$ & $\begin{array}{l}\text { Anxiety and depres- } \\
\text { sion }\end{array}$ & $\begin{array}{l}\text { Mixed nonactive } \\
\text { (waitlist, placebo) and } \\
\text { active (face-to-face or } \\
\text { alternative therapeutic } \\
\text { interventions) }\end{array}$ & 3113 & Up to 18 years & $\begin{array}{l}\text { Australia, Cana- } \\
\text { da, China, Ire- } \\
\text { land, Israel, the } \\
\text { Netherlands, } \\
\text { New Zealand, } \\
\text { Sweden, Thai- } \\
\text { land, the United } \\
\text { Kingdom, and the } \\
\text { United States }\end{array}$ \\
\hline $\begin{array}{l}\text { Vigerland et } \\
\text { al (2016) } \\
{[43]}\end{array}$ & $\begin{array}{l}\text { Meta-analysis of } \\
24 \text { RCTs }\end{array}$ & cCBT & $\begin{array}{l}\text { Multiple psychi- } \\
\text { atric and psychoso- } \\
\text { matic conditions }\end{array}$ & $\begin{array}{l}\text { Mixed nonactive } \\
\text { (waitlist) and active } \\
\text { (standard CBT, alter- } \\
\text { native intervention) }\end{array}$ & 1882 & Up to 18 years & $\begin{array}{l}\text { Australia, Cana- } \\
\text { da, Germany, the } \\
\text { Netherlands, } \\
\text { Sweden, and the } \\
\text { United States }\end{array}$ \\
\hline
\end{tabular}




\begin{tabular}{|c|c|c|c|c|c|c|c|}
\hline Author & Primary studies & $\begin{array}{l}\text { Intervention, digi- } \\
\text { tal platform }\end{array}$ & Outcome & $\begin{array}{l}\text { Comparison interven- } \\
\text { tions }\end{array}$ & $\begin{array}{l}\text { Total } \\
\text { sample }\end{array}$ & $\begin{array}{l}\text { Participants age } \\
\text { (range and mean, } \\
\text { if available) }\end{array}$ & $\begin{array}{l}\text { Geographical } \\
\text { coverage }\end{array}$ \\
\hline $\begin{array}{l}\text { Clarke et al } \\
(2015)[44]\end{array}$ & $\begin{array}{l}\text { Systematic re- } \\
\text { view of } 14 \text { RCTs } \\
\text { and } 14 \text { NRSs on } \\
21 \text { interventions }\end{array}$ & $\begin{array}{l}\text { Mixed web-based } \\
\text { interventions and } \\
\text { more than half } \\
(8 / 15) \text { cCBT }\end{array}$ & $\begin{array}{l}\text { Mental health pro- } \\
\text { motion and preven- } \\
\text { tion }\end{array}$ & $\begin{array}{l}\text { Mixed nonactive } \\
\text { (waitlist, placebo, no } \\
\text { intervention) and ac- } \\
\text { tive (limited interven- } \\
\text { tion) }\end{array}$ & 10,779 & $12-25$ years & $\begin{array}{l}\text { Australia, Cana- } \\
\text { da, China, Ger- } \\
\text { many, Ireland, Is- } \\
\text { rael, the Nether- } \\
\text { lands, Norway, } \\
\text { and the United } \\
\text { States }\end{array}$ \\
\hline
\end{tabular}

${ }^{\mathrm{a}} \mathrm{RCT}$ : randomized controlled trial.

${ }^{\mathrm{b}} \mathrm{NRS}$ : nonrandomized study.

${ }^{\mathrm{c}} \mathrm{NRT}$ : nonrandomized trial.

d cCBT: computerized cognitive behavioral therapy.

${ }^{\mathrm{e}} \mathrm{CBT}$ : cognitive behavioral therapy.

\section{Effectiveness Across Clinical Symptom Targets}

In terms of clinical outcomes, most systematic reviews and meta-analyses included in this review focused on anxiety $(n=4)$, depression $(n=3)$, anxiety and depression together $(n=11)$, or anxiety and depression with stress $(n=3)$. To a lesser degree, analyses focused on general well-being $(n=4)$. In addition, eating disorders $(n=2)$, psychosis $(n=2)$, attention-deficit/hyperactivity disorder (ADHD; $n=1)$, autism spectrum disorder $(n=1)$, sleep problems $(n=1)$, suicide prevention $(n=1)$, obsessive-compulsive disorder $(n=1)$, role functioning $(n=1)$, phobias $(n=1)$, and posttraumatic stress disorder $(n=1)$ were clinical outcomes explored in the reviews.

Evidence on the benefits of digital mental health interventions was found for anxiety, depression, and stress when compared with nonactive controls, defined primarily as groups to which no treatment was provided or on those put on a waitlist for services. However, compared with active controls, defined as those undergoing or receiving some type of treatment, they appear to be similarly effective (Table 2).

A meta-analysis by Harrer et al [34] on web-based interventions mostly delivered through a dedicated website found small effects on depression (Hedges $g=0.18$; 95\% CI 0.08-0.27), anxiety (Hedges $g=0.27$; 95\% CI 0.13-0.40), and stress (Hedges $g=0.20$; 95\% CI 0.02-0.38) compared with nonactive controls consisting of waitlist or placebo control groups.

A meta-analysis by Davies et al [31] on mixed web-based and computer-delivered interventions for depression, anxiety, and stress found a small effect of digital interventions in comparison with active controls that received alternative materials (for anxiety, pooled standardized mean difference [SMD] -0.18 ; $95 \% \mathrm{CI}-0.98$ to $0.62 ; P=.66$ and for depression, pooled SMD $-0.28 ; 95 \% \mathrm{CI}-0.75$ to $-0.20 ; P=.25)$, whereas a medium effect was found when compared with nonactive controls. When compared with a nonactive control, there was some effect of decreasing anxiety (pooled SMD $-0.56 ; 95 \% \mathrm{CI}-0.77$ to -0.35 ; $P<.001$ ), depression (pooled SMD $-0.43 ; 95 \% \mathrm{CI}-0.63$ to $-0.22 ; P<.001$ ), and stress (pooled SMD $-0.73 ; 95 \% \mathrm{CI}-1.27$ to $-0.19 ; P=.008)$.

A meta-analysis by Garrido et al [35] that focused on depression found a small pooled effect size of digital mental health interventions in comparison with nonactive controls (Cohen $d=0.33$; 95\% CI 0.11-0.55), whereas the pooled effect size of studies comparing an intervention group with active controls, mostly receiving alternative materials, including website content, showed no significant differences (Cohen $d=0.14$; 95\% CI -0.04 to 0.31 ).

A systematic review by Farrer et al [32] exploring 51 digital interventions using different delivery methods addressing mostly depression, anxiety, and stress found that nearly half of the interventions $(24 / 51,47 \%)$ were associated with at least one positive outcome after the intervention compared with the control group (nonactive and attention controls) and nearly one-third of the interventions $(15 / 51,29 \%)$ failed to report a significant effect. For interventions targeting both symptoms of depression and anxiety $(n=8)$, in comparison with mixed control groups (nonactive and active), effect sizes ranged significantly from -0.07 to 3.04 (overall median 0.54 ; [effect size] targeting depression symptoms $=0.48$ and targeting anxiety symptoms $=0.77$ ). For interventions targeting only anxiety $(n=10)$, effect sizes ranged from 0.07 to 2.66 (median 0.84 ). However, the authors of these reviews could not calculate effect sizes for almost two-thirds of the interventions $(33 / 51,64 \%)$ because of insufficient or unavailable meta-data across the reviewed studies [32].

Outcomes of interventions for ADHD, autism spectrum disorders, eating disorders, psychosis, and posttraumatic stress were reported in 3 systematic reviews and one meta-analysis [24,32,34]. Hollis et al [24] demonstrated inconsistent results on the effectiveness of digital interventions for ADHD, autism, psychosis, or eating disorders, limited by the small number of studies and the high degree of variability in reliance on evidence-based treatments. Farrer et al [32] demonstrated the effectiveness of virtual reality or video exposure interventions on arachnophobia or acrophobia. In addition, Harrer et al [34] found moderate effects on eating disorder symptoms (Hedges $g=0.52 ; 95 \%$ CI 0.22-0.83) and role functioning (Hedges $g=0.41$; 95\% CI 0.26-0.56) in comparison with active and nonactive controls (predominantly waitlist control) but no effect on general well-being in comparison with placebo intervention (Hedges $g=0.15 ; 95 \%$ CI -0.20 to 0.50 ). 
Table 2. Key findings of the included studies.

\begin{tabular}{|c|c|c|c|c|c|c|}
\hline Reference & Effectiveness & Contributing factors & $\begin{array}{l}\text { Cost-effec- } \\
\text { tiveness }\end{array}$ & $\begin{array}{l}\text { Inclusion of } \\
\text { data on low- } \\
\text { and middle- } \\
\text { income } \\
\text { countries }\end{array}$ & $\begin{array}{l}\text { Quality of included } \\
\text { studies }\end{array}$ & $\begin{array}{l}\text { Quality of } \\
\text { review (AM- } \\
\text { STAR }^{\text {a }} \text { ) }\end{array}$ \\
\hline $\begin{array}{l}\text { Barnes et } \\
\text { al }(2018) \\
{[28]}\end{array}$ & $\begin{array}{l}\text { Although early findings suggest } \\
\text { that therapeutic games have the } \\
\text { potential to lead to clinically } \\
\text { measurable reductions in } \\
\text { symptoms in adolescents with } \\
\text { anxiety, evidence on the effec- } \\
\text { tiveness is extremely limited. } \\
\text { On the basis of } 2 \text { RCTs }{ }^{b} \text { includ- } \\
\text { ed in this review, no difference } \\
\text { in anxiety outcomes is found } \\
\text { between the intervention and } \\
\text { control groups (alternative } \\
\text { nontherapeutic videogame). }\end{array}$ & Not discussed & $\begin{array}{l}\text { Not dis- } \\
\text { cussed }\end{array}$ & $\begin{array}{l}\text { Limited } \\
\text { (China and } \\
\text { Hong Kong) }\end{array}$ & $\begin{array}{l}\text { Mean rating of } 75 \% \\
\text { using mixed meth- } \\
\text { ods appraisal tool. } \\
\text { Only } 2 \text { RCTs includ- } \\
\text { ed in the review. }\end{array}$ & $\begin{array}{l}\text { Critically } \\
\text { low }\end{array}$ \\
\hline $\begin{array}{l}\text { Bry et al } \\
(2018) \text { [29] }\end{array}$ & $\begin{array}{l}\text { Evidence-based treatment con- } \\
\text { tent within consumer smart- } \\
\text { phone apps marketed for child } \\
\text { and adolescent anxiety is scant, } \\
\text { and only a few comprehensive } \\
\text { anxiety self-management apps } \\
\text { are identified. Half of the sam- } \\
\text { pled apps for anxiety include } \\
\text { any evidence-based treatment } \\
\text { component, and } 23 \% \text { included } \\
\text { two or more evidence-based } \\
\text { components. }\end{array}$ & Not discussed & $\begin{array}{l}\text { Low cost but } \\
\text { effectiveness } \\
\text { unknown }\end{array}$ & No & $\mathrm{N} / \mathrm{A}^{\mathrm{c}}$ & N/A \\
\hline $\begin{array}{l}\text { Grist et al } \\
\text { (2017) [30] }\end{array}$ & $\begin{array}{l}\text { Authors conclude that there is } \\
\text { currently no evidence to sup- } \\
\text { port the effectiveness of apps } \\
\text { for adolescents with mental } \\
\text { health problems. In } 2 \text { RCTs on } \\
\text { mobile app for depression, } \\
\text { anxiety, and stress, no signifi- } \\
\text { cant effect is found between } \\
\text { intervention (app with self- } \\
\text { monitoring) and control (no } \\
\text { self-monitoring) groups. Accept- } \\
\text { ability is generally rated aver- } \\
\text { age to high, with adherence } \\
\text { ranging from } 65 \% \text { to } 83 \% \text {. }\end{array}$ & $\begin{array}{l}\text { Specific factors: privacy, safety, } \\
\text { discretion, and data security; cred- } \\
\text { ibility of design and visual appear- } \\
\text { ance; engaging and interactive } \\
\text { content; concise, interesting, and } \\
\text { trustworthy information; reminders } \\
\text { to use; and personalization allowed }\end{array}$ & $\begin{array}{l}\text { Not dis- } \\
\text { cussed }\end{array}$ & No & $\begin{array}{l}\text { Issues with quality, } \\
\text { including small sam- } \\
\text { ple size. Only } 2 \\
\text { small RCTs included } \\
\text { in the review, both } \\
\text { without adequate } \\
\text { control group. }\end{array}$ & $\begin{array}{l}\text { Critically } \\
\text { low }\end{array}$ \\
\hline $\begin{array}{l}\text { Hollis et al } \\
\text { (2017) [24] }\end{array}$ & $\begin{array}{l}\mathrm{cCBT}^{\mathrm{d}} \text { provides clinical bene- } \\
\text { fits for depression and anxiety } \\
\text { when compared with inactive } \\
\text { control (waitlist). The benefits } \\
\text { for attention deficit hyperactiv- } \\
\text { ity disorder and autism are in- } \\
\text { consistent, for psychosis are } \\
\text { unknown, and eating disorders } \\
\text { are no better than waitlist con- } \\
\text { trol in regard to symptomology. }\end{array}$ & $\begin{array}{l}\text { Self-guided cCBT has poor uptake } \\
\text { and adherence. Human involve- } \\
\text { ment is positively associated with } \\
\text { adherence. Adolescents and young } \\
\text { people prefer face-to-face over } \\
\text { web-based interventions. Specific } \\
\text { factors: privacy, safety, discretion, } \\
\text { and anonymity; providing concise, } \\
\text { interesting, and trustworthy infor- } \\
\text { mation; and ability to complete } \\
\text { interventions on own terms and } \\
\text { pace. }\end{array}$ & $\begin{array}{l}\text { Authors note } \\
\text { a consider- } \\
\text { able lack of } \\
\text { evidence }\end{array}$ & $\begin{array}{l}\text { Limited } \\
\text { (China) }\end{array}$ & $\begin{array}{l}\text { Most studies }(18 / 21) \\
\text { rated as moderate } \\
\text { quality, } 2 \text { rated as } \\
\text { low quality, and } 1 \\
\text { rated as high quality } \\
\text { using AMSTAR. } \\
\text { Methodological is- } \\
\text { sues and high level } \\
\text { of heterogeneity in } \\
\text { the included studies. }\end{array}$ & $\begin{array}{l}\text { Critically } \\
\text { low }\end{array}$ \\
\hline
\end{tabular}




\begin{tabular}{|c|c|c|c|c|c|c|}
\hline Reference & Effectiveness & Contributing factors & $\begin{array}{l}\text { Cost-effec- } \\
\text { tiveness }\end{array}$ & $\begin{array}{l}\text { Inclusion of } \\
\text { data on low- } \\
\text { and middle- } \\
\text { income } \\
\text { countries }\end{array}$ & $\begin{array}{l}\text { Quality of included } \\
\text { studies }\end{array}$ & $\begin{array}{l}\text { Quality of } \\
\text { review (AM- } \\
\text { STAR }^{\mathrm{a}} \text { ) }\end{array}$ \\
\hline $\begin{array}{l}\text { Davies et } \\
\text { al (2014) } \\
{[31]}\end{array}$ & $\begin{array}{l}\text { Web-based and computer-deliv- } \\
\text { ered interventions are found } \\
\text { effective in improving students' } \\
\text { depression (pooled SMD } \\
-0.43 ; 95 \% \text { CI }-0.63 \text { to }-0.22 \text {; } \\
P<.001 \text { ), anxiety (pooled SMD } \\
-0.56 ; 95 \% \text { CI }-0.77 \text { to }-0.35 \text {; } \\
P<.001 \text { ), and stress (pooled } \\
\text { SMD }-0.73 ; 95 \% \text { CI }-1.27 \text { to } \\
-0.19 ; P=.008 \text { ) outcomes when } \\
\text { compared with inactive controls } \\
\text { (no treatment, waitlist). When } \\
\text { compared with active controls } \\
\text { (alternative materials), no bene- } \\
\text { fits are found for depression, } \\
\text { anxiety, and stress. }\end{array}$ & Not discussed & $\begin{array}{l}\text { Not dis- } \\
\text { cussed }\end{array}$ & No & $\begin{array}{l}\text { A moderate risk of } \\
\text { bias. Quality issues } \\
\text { with reporting of } \\
\text { methodology, data, } \\
\text { and outcome mea- } \\
\text { sures. Only } 3 \text { studies } \\
\text { with active control, } \\
\text { with reported } \\
\text { skewed data. Hetero- } \\
\text { geneity of interven- } \\
\text { tions. }\end{array}$ & Moderate \\
\hline $\begin{array}{l}\text { Farrer et al } \\
(2013)[32]\end{array}$ & $\begin{array}{l}\text { Approximately half }(24 / 51) \text { of } \\
\text { the technology-based mental } \\
\text { health interventions targeting } \\
\text { tertiary students with anxiety } \\
\text { or depression are associated } \\
\text { with at least one significant } \\
\text { positive outcome, and approxi- } \\
\text { mately one-third ( } 15 / 51) \text { fail to } \\
\text { find a significant effect. Effect } \\
\text { size for interventions targeting } \\
\text { symptoms of depression and } \\
\text { anxiety range from }-0.07 \text { to } \\
3.04 \text { (median } 0.54 \text {; depres- } \\
\text { sion=0.48; anxiety=0.77). Ef- } \\
\text { fect size for interventions target- } \\
\text { ing symptoms of anxiety range } \\
\text { from } 0.07 \text { to } 2.66 \text { (median } \\
0.84) \text {. cCBT was the most de- } \\
\text { ployed therapy in } 25 \text { of } 51 \text { of } \\
\text { the interventions. }\end{array}$ & Not discussed & $\begin{array}{l}\text { Included } \\
\text { studies do } \\
\text { not report } \\
\text { cost-effec- } \\
\text { tiveness }\end{array}$ & $\begin{array}{l}\text { Limited } \\
\text { (China) }\end{array}$ & $\begin{array}{l}\text { Mean rating } 4.42 \text { out } \\
\text { of } 9 \text { using Cochrane } \\
\text { Effective Practice } \\
\text { and Organisation of } \\
\text { Care Group. } \\
\text { Methodological is- } \\
\text { sues with reporting } \\
\text { on randomization, } \\
\text { intended outcomes, } \\
\text { and heterogeneity of } \\
\text { interventions. Insuf- } \\
\text { ficient data in more } \\
\text { than half of the stud- } \\
\text { ies (14/27) to calcu- } \\
\text { late effect sizes. }\end{array}$ & Low \\
\hline $\begin{array}{l}\text { Valimaki } \\
\text { et al (2017) } \\
{[33]}\end{array}$ & $\begin{array}{l}\text { Web-based mental health inter- } \\
\text { ventions yield statistically sig- } \\
\text { nificant effect on depressive } \\
\text { ( } P=.02 ; \text { median } 1.68 ; 95 \% \text { CI } \\
3.11 \text { to } 0.25) \text { and anxiety } \\
\text { symptoms ( } P<.001 ; \text { median } \\
1.47 ; 95 \% \text { CI } 2.36 \text { to } 0.59) \\
\text { when compared with control } \\
\text { group (type not specified), but } \\
\text { not on stress ( } P=.14 ; \text { median } \\
1.06 ; 95 \% \text { CI } 2.44 \text { to } 0.33) \text {. } \\
\text { After } 6 \text { months of intervention, } \\
\text { significant improvement is } \\
\text { found on depressive symptoms } \\
(P=.01 ; \text { median } 1.78 ; 95 \% \text { CI } \\
3.20 \text { to } 0.37) \text {, on anxiety symp- } \\
\text { toms ( } P<.001 ; \text { median } 1.47 ; \\
95 \% \text { CI } 2.36 \text { to } 0.59) \text {, and on } \\
\text { moods and feelings }(P=.04 ; \\
\text { median } 5.55 ; 95 \% \text { CI } 10.88 \text { to } \\
0.22) \text {. Dropout of those in inter- } \\
\text { vention groups was higher than } \\
\text { those in control groups. }\end{array}$ & $\begin{array}{l}\text { Interventions with human ele- } \\
\text { ments, such as face-to-face guid- } \\
\text { ance or telephone follow-ups, are } \\
\text { associated with adherence and ef- } \\
\text { fect. }\end{array}$ & $\begin{array}{l}\text { Included } \\
\text { studies do } \\
\text { not assess } \\
\text { costs. Au- } \\
\text { thors note a } \\
\text { considerable } \\
\text { lack of evi- } \\
\text { dence }\end{array}$ & $\begin{array}{l}\text { Limited } \\
\text { (China) }\end{array}$ & $\begin{array}{l}\text { Some risk of bias } \\
\text { using Review Man- } \\
\text { ager. Issues include } \\
\text { biases related to attri- } \\
\text { tion rates, selective } \\
\text { reporting, and small } \\
\text { sample sizes. Mixed } \\
\text { control groups. }\end{array}$ & High \\
\hline
\end{tabular}




\begin{tabular}{|c|c|c|c|c|c|c|}
\hline Reference & Effectiveness & Contributing factors & $\begin{array}{l}\text { Cost-effec- } \\
\text { tiveness }\end{array}$ & $\begin{array}{l}\text { Inclusion of } \\
\text { data on low- } \\
\text { and middle- } \\
\text { income } \\
\text { countries }\end{array}$ & $\begin{array}{l}\text { Quality of included } \\
\text { studies }\end{array}$ & $\begin{array}{l}\text { Quality of } \\
\text { review (AM- } \\
\left.\text { STAR }^{\mathrm{a}}\right)\end{array}$ \\
\hline $\begin{array}{l}\text { Harrer et al } \\
(2019)[34]\end{array}$ & $\begin{array}{l}\text { Internet interventions for univer- } \\
\text { sity students' mental health } \\
\text { have a small effect on anxiety } \\
\text { (Hedges } g=0.27 ; 95 \% \text { CI } 0.13 \\
\text { to } 0.40 \text { ), depression (Hedges } \\
g=0.18 ; 95 \% \text { CI } 0.08 \text { to } 0.27 \text { ), } \\
\text { and stress (Hedges } g=0.20 ; \\
95 \% \text { CI } 0.02 \text { to } 0.38 \text { ) when } \\
\text { compared with nonactive con- } \\
\text { trols. Moderate effects were } \\
\text { found on eating disorder symp- } \\
\text { toms (Hedges } g=0.52 ; 95 \% \text { CI } \\
0.22 \text { to } 0.83 \text { ) and role function- } \\
\text { ing (Hedges } g=0.41 ; 95 \% \text { CI } \\
0.26 \text { to } 0.56 \text { ). Effects on well - } \\
\text { being are nonsignificant } \\
\text { (Hedges } g=0.15 ; 95 \% \text { CI }-0.20 \\
\text { to } 0.50 \text { ). }\end{array}$ & $\begin{array}{l}\text { Guidance does not significantly } \\
\text { affect intervention efficacy } \\
(P \geq .05) \text {. }\end{array}$ & $\begin{array}{l}\text { Not dis- } \\
\text { cussed }\end{array}$ & $\begin{array}{l}\text { Limited (Ro- } \\
\text { mania) }\end{array}$ & $\begin{array}{l}\text { Half of the studies } \\
\text { with high risk of } \\
\text { bias. Moderate to } \\
\text { substantial level of } \\
\text { heterogeneity and } \\
\text { selective reporting. }\end{array}$ & Low \\
\hline $\begin{array}{l}\text { Garrido et } \\
\text { al (2019) } \\
{[35]}\end{array}$ & $\begin{array}{l}\text { Digital interventions work bet- } \\
\text { ter than no intervention (Cohen } \\
d=0.33 \text {; } 95 \% \text { CI } 0.11 \text { to } 0.55 \text { ) } \\
\text { but not better than active alter- } \\
\text { natives (alternative web-based } \\
\text { materials; Cohen } d=0.14 ; 95 \% \\
\text { CI }-0.04 \text { to } 0.31 \text { ) in improving } \\
\text { depression in young people, } \\
\text { when results of different studies } \\
\text { are pooled together. Most inter- } \\
\text { ventions were based on CBT } \\
\text { Authors conclude that interven- } \\
\text { tions may be clinically signifi- } \\
\text { cant only if supervised. Engage- } \\
\text { ment and adherence rates are } \\
\text { low. }\end{array}$ & $\begin{array}{l}\text { Interventions with supervision } \\
\text { have a higher pooled effect size } \\
\text { than those without supervision } \\
\text { (studies with no intervention con- } \\
\text { trols: Cohen } d=0.52 ; 95 \% \text { CI } 0.23 \\
\text { to } 0.80 \text { and studies with active } \\
\text { controls: Cohen } d=0.49 ; 95 \% \text { CI } \\
-0.11 \text { to } 1.01 \text { ). Specific factors: } \\
\text { credibility of design and visual } \\
\text { appearance; concise, interesting, } \\
\text { and trustworthy resources; engag- } \\
\text { ing and interactive tools and con- } \\
\text { tent; esthetically attractive; relat- } \\
\text { able situations, characters, or } \\
\text { avatars; and reflect local and cul- } \\
\text { tural differences and needs. Tech- } \\
\text { nical glitches as a barrier to com- } \\
\text { plete interventions. }\end{array}$ & $\begin{array}{l}\text { Not dis- } \\
\text { cussed }\end{array}$ & $\begin{array}{l}\text { Limited } \\
\text { (China, } \\
\text { Hong Kong, } \\
\text { and Chile) }\end{array}$ & $\begin{array}{l}\text { On the basis of } \\
\text { Joanna Brigg Insti- } \\
\text { tute appraisal tool } \\
\text { and CONSORT } \\
\text { (Consolidated Stan- } \\
\text { dards of Reporting } \\
\text { Trials), } 32 \text { of } 41 \\
\text { studies with high or } \\
\text { unclear overall bias } \\
\text { and } 9 \text { of } 41 \text { with low } \\
\text { overall bias. }\end{array}$ & Low \\
\hline $\begin{array}{l}\text { Pretorius et } \\
\text { al }(2019) \\
{[36]}\end{array}$ & N/A & $\begin{array}{l}\text { Young people value web-based } \\
\text { services because of anonymity, } \\
\text { accessibility, self-reliance, and } \\
\text { ease of use. Theoretical frame- } \\
\text { works, including self-determina- } \\
\text { tion theory and help-seeking mod- } \\
\text { el, should be deployed in research. } \\
\text { Specific factors: anonymity, priva- } \\
\text { cy, safety, and discretion; site } \\
\text { moderation by professionals; } \\
\text { credibility of design and visual } \\
\text { appearance; concise, interesting, } \\
\text { and trustworthy information; esthet- } \\
\text { ically attractive; flexibility, self- } \\
\text { reliance, and control; and 24-h } \\
\text { availability. }\end{array}$ & $\begin{array}{l}\text { Not dis- } \\
\text { cussed }\end{array}$ & No & $\begin{array}{l}\text { Moderate to strong } \\
\text { using Critical Ap- } \\
\text { praisal Skills Pro- } \\
\text { gram. Heterogeneity } \\
\text { of interventions. On- } \\
\text { ly } 1 \text { RCT included in } \\
\text { the review. }\end{array}$ & $\begin{array}{l}\text { Critically } \\
\text { low }\end{array}$ \\
\hline $\begin{array}{l}\text { Ridout et al } \\
(2018) \text { [37] }\end{array}$ & $\begin{array}{l}\text { Social networking sites target- } \\
\text { ing mental health have signifi- } \\
\text { cant improvement in mental } \\
\text { health knowledge and a number } \\
\text { of depressive symptoms in } \\
\text { young people, but no improve- } \\
\text { ment in anxiety or psychosis } \\
\text { symptoms. The results are not } \\
\text { compared with a control group. }\end{array}$ & $\begin{array}{l}\text { Young people value involvement } \\
\text { of professionals and peers in social } \\
\text { networking sites. }\end{array}$ & $\begin{array}{l}\text { Authors con- } \\
\text { clude that } \\
\text { web-based } \\
\text { interventions } \\
\text { are cost-ef- } \\
\text { fective but } \\
\text { provide no } \\
\text { evidence }\end{array}$ & $\begin{array}{l}\text { Limited } \\
\text { (China and } \\
\text { Hong Kong) }\end{array}$ & $\begin{array}{l}\text { No quality assess- } \\
\text { ment performed. On } \\
\text { the basis of descrip- } \\
\text { tive studies, no } \\
\text { RCTs included in } \\
\text { the review. }\end{array}$ & $\begin{array}{l}\text { Critically } \\
\text { low }\end{array}$ \\
\hline
\end{tabular}




\begin{tabular}{|c|c|c|c|c|c|c|}
\hline Reference & Effectiveness & Contributing factors & $\begin{array}{l}\text { Cost-effec- } \\
\text { tiveness }\end{array}$ & $\begin{array}{l}\text { Inclusion of } \\
\text { data on low- } \\
\text { and middle- } \\
\text { income } \\
\text { countries }\end{array}$ & $\begin{array}{l}\text { Quality of included } \\
\text { studies }\end{array}$ & $\begin{array}{l}\text { Quality of } \\
\text { review (AM- } \\
\left.\text { STAR }^{a}\right)\end{array}$ \\
\hline $\begin{array}{l}\text { Podina et } \\
\text { al }(2016) \\
{[38]}\end{array}$ & $\begin{array}{l}\text { cCBT is as effective as standard } \\
\text { CBT (Hedges } g=0.295 \text { ) and } \\
\text { more effective than waitlist } \\
\text { (Hedges } g=1.410 \text { ) in reducing } \\
\text { anxiety symptoms in anxious } \\
\text { children and adolescents. }\end{array}$ & Not discussed & $\begin{array}{l}\text { Not dis- } \\
\text { cussed }\end{array}$ & No & $\begin{array}{l}\text { No quality assess- } \\
\text { ment performed. No } \\
\text { publication bias } \\
\text { found. Only } 8 \text { RCTs } \\
\text { included in the re- } \\
\text { view. }\end{array}$ & $\begin{array}{l}\text { Critically } \\
\text { low }\end{array}$ \\
\hline $\begin{array}{l}\text { Ebert et al } \\
(2015) \text { [39] }\end{array}$ & $\begin{array}{l}\text { cCBT for youth is associated } \\
\text { with significant moderate to } \\
\text { large effects on symptoms of } \\
\text { anxiety (Hedges } g=0.68 ; 95 \% \\
\text { CI } 0.45 \text { to } 0.92 ; P<.001 \text { ) and } \\
\text { depression (Hedges } g=0.68 \text {; } \\
95 \% \text { CI } 0.45 \text { to } 0.92 ; P<.001 \text { ) } \\
\text { in comparison with nonactive } \\
\text { controls. Effect size on symp- } \\
\text { toms of anxiety or depression } \\
\text { for cCBT was similar to face- } \\
\text { to-face CBT (Hedges } g=0.72 \\
\text { vs Hedges } g=0.66 \text { ) and higher } \\
\text { than face-to-face CBT targeting } \\
\text { depression (Hedges } g=0.35 \text { ). }\end{array}$ & $\begin{array}{l}\text { No association between parental } \\
\text { involvement and better outcomes } \\
\text { (without parental involvement: } \\
\text { Hedges } g=0.83 ; 95 \% \text { CI } 0.53 \text { to } \\
1.13 ; P<.001 ; \mathrm{NNT}^{\mathrm{g}}=2.26 \text { and } \\
\text { with parental involvement: Hedges } \\
g=0.64 ; 95 \% \text { CI } 0.40 \text { to } 0.88 ; \\
P<.001 ; \mathrm{NNT}=2.86 \text { ) }\end{array}$ & $\begin{array}{l}\text { Not dis- } \\
\text { cussed }\end{array}$ & No & $\begin{array}{l}\text { Low risk of bias } \\
\text { overall. Low hetero- } \\
\text { geneity }\end{array}$ & Low \\
\hline $\begin{array}{l}\text { Pennant et } \\
\text { al (2015) } \\
{[40]}\end{array}$ & $\begin{array}{l}\text { cCBT has positive effects for } \\
\text { symptoms of anxiety (SMD } \\
0.77 ; 95 \% \text { CI } 1.45 \text { to } 0.09 ; \mathrm{n}=6 \text {; } \\
\text { number of participants=220) } \\
\text { and depression (SMD } 0.62 ; \\
95 \% \text { CI } 1.13 \text { to } 0.11 ; \mathrm{n}=7 ; \\
\text { number of participants=279) } \\
\text { for young people with risk of } \\
\text { diagnosed anxiety and depres- } \\
\text { sion disorders. cCBT has lower } \\
\text { effect size on anxiety (SMD } \\
0.15 ; 95 \% \text { CI } 0.26 \text { to } 0.03 ; \\
\text { number of participants=1273) } \\
\text { and depression (SMD } 0.15 ; \\
95 \% \text { CI } 0.26 \text { to } 0.03 \text {; number } \\
\text { of participants=1280) in the } \\
\text { general population. Evidence } \\
\text { for interventions other than } \\
\text { cCBT is sparse and inconclu- } \\
\text { sive. }\end{array}$ & Not discussed & $\begin{array}{l}\text { Not dis- } \\
\text { cussed }\end{array}$ & $\begin{array}{l}\text { Limited } \\
\text { (China) }\end{array}$ & $\begin{array}{l}\text { On the basis of } \\
\text { Grading of Recom- } \\
\text { mendations, Assess- } \\
\text { ment, Development } \\
\text { and Evaluation evi- } \\
\text { dence quality re- } \\
\text { view, most studies } \\
\text { rated from very low } \\
(1 / 17) \text { to low }(11 / 17) \\
\text { to moderate }(5 / 17) \text {. } \\
\text { Heterogeneity associ- } \\
\text { ated with number of } \\
\text { outcomes. }\end{array}$ & $\begin{array}{l}\text { Critically } \\
\text { low }\end{array}$ \\
\hline $\begin{array}{l}\text { Ye et al } \\
(2014)[41]\end{array}$ & $\begin{array}{l}\text { When compared with inactive } \\
\text { controls, cCBT is effective in } \\
\text { reducing anxiety symptoms } \\
\text { (SMD }-0.52 ; 95 \% \mathrm{CI}-0.90 \text { to } \\
-0.14) \text { but not depression } \\
(\mathrm{SMD}-0.16 ; 95 \% \mathrm{CI}-0.44 \text { to } \\
0.12) \text {. No significant difference } \\
\text { is found when compared with } \\
\text { standard face-to-face CBT, } \\
\text { suggesting it is as effective. }\end{array}$ & Not discussed & $\begin{array}{l}\text { Included } \\
\text { studies do } \\
\text { not report on } \\
\text { cost-effec- } \\
\text { tiveness }\end{array}$ & No & $\begin{array}{l}\text { On the basis of } \\
\text { Quality Assessment } \\
\text { Tool for Quantita- } \\
\text { tive Studies, studies } \\
\text { rated high ( } 3 / 7) \text { and } \\
\text { moderate (4/7) quali- } \\
\text { ty. Only } 7 \text { RCTs in- } \\
\text { cluded in the review. }\end{array}$ & $\begin{array}{l}\text { Critically } \\
\text { low }\end{array}$ \\
\hline
\end{tabular}




\begin{tabular}{|c|c|c|c|c|c|c|}
\hline Reference & Effectiveness & Contributing factors & $\begin{array}{l}\text { Cost-effec- } \\
\text { tiveness }\end{array}$ & $\begin{array}{l}\text { Inclusion of } \\
\text { data on low- } \\
\text { and middle- } \\
\text { income } \\
\text { countries }\end{array}$ & $\begin{array}{l}\text { Quality of included } \\
\text { studies }\end{array}$ & $\begin{array}{l}\text { Quality of } \\
\text { review (AM- } \\
\text { STAR }^{\mathrm{a}} \text { ) }\end{array}$ \\
\hline $\begin{array}{l}\text { Grist et al } \\
(2019) \text { [42] }\end{array}$ & $\begin{array}{l}\text { A small effect ( } \mathrm{n}=8 \text {; Hedges } \\
g=0.41 ; 95 \% \text { CI } 0.08 \text { to } 0.73 \text {; } \\
P<.01 \text { ) is found in technology- } \\
\text { delivered mental health inter- } \\
\text { ventions related to attention } \\
\text { bias modification when com- } \\
\text { pared with waitlist controls. } \\
\text { Although cCBT interventions } \\
\text { yield a medium effect size, at- } \\
\text { tention bias modification pro- } \\
\text { grams yield a small effect size, } \\
\text { and cognitive bias modification } \\
\text { programs yield no effect size. }\end{array}$ & $\begin{array}{l}\text { Therapist support (Cochran } \\
\mathrm{Q}=27.28 ; P<.001) \text { as well as } \\
\text { parental involvement (Cochran } \\
\mathrm{Q}=24.43 ; P<.001 \text { ) have a signifi- } \\
\text { cant effect on effectiveness of and } \\
\text { adherence to an intervention. } \\
\text { Therapist involvement yields a } \\
\text { higher effect size ( } \mathrm{n}=9 ; \text { Hedges } \\
g=0.87 ; 95 \% \text { CI } 0.68 \text { to } 1.06 ; \\
P<.001) \text { than predominantly or } \\
\text { purely self-administered interven- } \\
\text { tions. }\end{array}$ & $\begin{array}{l}\text { Authors note } \\
\text { a consider- } \\
\text { able lack of } \\
\text { evidence }\end{array}$ & $\begin{array}{l}\text { Limited } \\
\text { (China) }\end{array}$ & $\begin{array}{l}\text { Most studies rated as } \\
\text { low quality and un- } \\
\text { clear risk using } \\
\text { Cochrane Risk of } \\
\text { Bias Tool. Most } \\
\text { studies (29/34) con- } \\
\text { ducted by program } \\
\text { developer. Method- } \\
\text { ological limitations, } \\
\text { small sample size, } \\
\text { and nonblinding par- } \\
\text { ticipants. }\end{array}$ & Low \\
\hline $\begin{array}{l}\text { Vigerland } \\
\text { et al (2016) } \\
{[43]}\end{array}$ & $\begin{array}{l}\text { cCBT yields moderate effects } \\
\text { when compared with waitlist } \\
\text { controls (Hedges } g=0.62 ; 95 \% \\
\text { CI } 0.41 \text { to } 0.84 \text { ). }\end{array}$ & Not discussed & $\begin{array}{l}\text { Authors note } \\
\text { a consider- } \\
\text { able lack of } \\
\text { evidence }\end{array}$ & No & $\begin{array}{l}\text { Quality varied large- } \\
\text { ly across the studies; } \\
\text { Moncrieff mean } \\
30.2 \text { of } 46 \text {. Hetero- } \\
\text { geneity of measures } \\
\text { included. }\end{array}$ & Low \\
\hline $\begin{array}{l}\text { Clarke et al } \\
(2015)[44]\end{array}$ & $\begin{array}{l}\text { There is some evidence that } \\
\text { skills-based interventions pre- } \\
\text { sented in a module-based for- } \\
\text { mat can have a significant im- } \\
\text { pact on promoting adolescent } \\
\text { mental health and that cCBT } \\
\text { has significant positive effects } \\
\text { on adolescents' anxiety and } \\
\text { depression symptoms; however, } \\
\text { research is limited. Improve- } \\
\text { ments of symptoms are main- } \\
\text { tained at } 6 \text { and } 12 \text { months. }\end{array}$ & $\begin{array}{l}\text { Face-to-face and web-based sup- } \\
\text { port are associated with improved } \\
\text { program completion and out- } \\
\text { comes. }\end{array}$ & $\begin{array}{l}\text { Not dis- } \\
\text { cussed }\end{array}$ & $\begin{array}{l}\text { Limited } \\
\text { (China) }\end{array}$ & $\begin{array}{l}\text { On the basis of } \\
\text { Quality Assessment } \\
\text { Tool for Quantita- } \\
\text { tive Studies, quality } \\
\text { varied significantly } \\
\text { from weak (12/20) } \\
\text { to moderate or } \\
\text { strong ( } 7 / 20) \text {. Issues } \\
\text { include a small } \\
\text { number of studies, } \\
\text { poor sampling, and } \\
\text { heterogeneity across } \\
\text { interventions. }\end{array}$ & Low \\
\hline
\end{tabular}

aMSTAR: A Measurement Tool to Assess Systematic Reviews.

${ }^{\mathrm{b}} \mathrm{RCT}$ : randomized controlled trial.

${ }^{\mathrm{c}} \mathrm{N} / \mathrm{A}$ : not applicable. This is a systematic review of apps and not studies, and therefore, quality assessment is not applicable.

$\mathrm{d}_{\mathrm{cCBT}}$ : computerized cognitive behavioral therapy.

${ }^{\text {e }}$ SMD: standardized mean difference.

${ }^{\mathrm{f}} \mathrm{CBT}$ : cognitive behavioral therapy.

${ }^{\mathrm{g}} \mathrm{NNT}$ : number needed to treat.

In conclusion, converging evidence across reviews suggests that digital health interventions have a small to medium effect when compared with nonactive controls (ie, waitlist or placebo). When compared with active controls, digital health interventions appear to be comparable, although findings varied by targeted set of symptoms, with evidence of effectiveness most apparent for anxiety and depression and to a lesser extent for stress. Inconclusive results across other symptom types were because of the limited number of trials conducted to date.

\section{Effectiveness of Clinical Interventions}

Most systematic reviews and meta-analyses have reported findings across studies that test the effectiveness of the implementation of computerized cognitive behavioral therapy (cCBT) $[33,34,38-42,44]$. Investigations of digital mental health interventions other than cCBT are rare, and thus, our analysis on the effectiveness of digital clinical interventions across studies focuses exclusively on cCBT.

According to 4 reviews, there is no significant difference in the effectiveness between cCBT delivered through a digital platform and standard face-to-face cognitive behavioral therapy (CBT) $[38,39,41]$. However, there is some evidence of benefits compared with nonactive controls [31,34,35,39,42].

Ye et al [41] found no statistical difference between internet-based CBT and face-to-face interventions, suggesting that the digital format may retain effectiveness. However, when compared with nonactive controls, cCBT was effective in reducing anxiety symptoms (SMD $-0.52 ; 95 \% \mathrm{CI}-0.90$ to -0.14 ) but not in reducing depression (SMD 0.16; 95\% CI 0.44-0.12) [41]. A meta-analysis by Podina et al [38] found that cCBT was as effective as standard CBT (Hedges $g=0.295$ ) and more effective than waitlist (Hedges $g=1.410$ ) in reducing 
anxiety symptoms. Similarly, Vigerland et al [43] found a moderate effect on social anxiety disorder compared with waitlist controls (Hedges $g=0.62 ; 95 \%$ CI $0.41-0.84$ ). In 2 separate trials, older participants were found to gain greater clinical benefits compared with younger participants (slope $=0.514)$ [24,38].

Ebert et al [39] found that the overall mean effect size of cCBT on symptoms of anxiety or depression was Hedges $g=0.72(95 \%$ CI 0.55-0.90) at posttest after controlling the baseline levels. This effect is similar to the effect of traditional CBT for anxiety (0.66) and higher than that of CBT for the treatment of depression in youth (0.35). When compared with a nonactive control, cCBT was effective in targeting anxiety (Hedges $g=0.68 ; 95 \%$ CI $0.45-0.92 ; P<.001$ ) and depression (Hedges $g=0.76 ; 95 \%$ CI $0.41-0.12 ; P<.001)$.

With regard to studies with mixed comparison groups (active and nonactive), Harrer et al [34] found cCBT interventions more effective than others (eg, relationship skills training and emotional disclosure) for some conditions (depression: Hedges $g=0.28 ; 95 \%$ CI $0.15-0.40$ vs Hedges $g=0.04 ; 95 \%$ CI -0.23 to 0.30 ; number needed to treat $[\mathrm{NNT}]=6.41$ vs 4.4 .5 and anxiety: Hedges $g=0.36$; $95 \%$ CI 0.23-0.50 vs Hedges $g=-0.06$; 95\% CI -0.46 to 0.35 ; NNT: 5 vs 29.41). Similarly, Clarke et al [44] found that module-based cCBT showed significant positive effects in reducing depression and anxiety, thoughts of self-harm, and hopelessness and in improving sense of control.

Pennant et al [40] demonstrated greater effects when cCBT is targeted to young people assessed at risk of anxiety or depression, in comparison with the general population of young people. Among young people with elevated depression or anxiety symptom scores, cCBT had positive effects on anxiety (SMD 0.77; 95\% CI 1.45-0.09; number of studies, $\mathrm{n}=6$; number of participants=220) and depression (SMD 0.62; 95\% CI $1.13-0.11 ; n=7$; number of participants $=279$ ), whereas in the general population of young people, effect sizes were smaller (anxiety: SMD 0.15; 95\% CI 0.26-0.03; number of participants $=1273$ and depression: SMD $0.15 ; 95 \%$ CI 0.26-0.03; number of participants $=1280$ ) [33]. Similar findings were also found in 2 other systematic reviews [34,44].

With regard to non-cCBT interventions, a small effect size of attention bias modification programs for anxiety and depression was observed $(\mathrm{n}=8$; Hedges $g=0.41 ; 95 \%$ CI $0.08-0.73 ; P<.01)$, whereas no benefit of cognitive bias modification programs or other interventions over either passive or active control groups (other therapeutically active conditions, attention or placebo training conditions, and waitlist) was observed [42].

\section{Effectiveness of Digital Platforms}

Only 4 systematic reviews have reported findings on digital platforms used to deliver digital mental health services. These included social networking sites [37], mental health apps [18,29], and therapeutic video games [28].

A systematic review by Ridout and Campbell [37] on social networking sites targeting mental health found no evidence of improvement in anxiety or psychosis symptoms in young people, whereas it found improvements in enhancing mental health knowledge and the number of depressive symptoms. Among the sites, the review suggested that the closed Facebook-like moderated online social therapy platforms as well as the YBMen project that used Facebook was effective, although there was no evidence of the effectiveness of other social networking platforms (the MindMax and Ching Story) included in the review [37]. In another systematic review, Grist et al [18] found no evidence to support the effectiveness of apps designed for adolescents with mental health conditions.

One reason for the lack of effectiveness across specific platforms may be attributable to a limited evidence base for many of the interventions available. For example, a review of 121 anxiety apps available in app stores (Google and Apple) by Bry et al [29] found that only a limited number of these apps were evidence based. Only one-sixth of the apps included educational information on the definition, symptoms, and treatment of anxiety. Half had at least one evidence-based treatment component, and one-fourth had more than one evidence-based treatment component, such as exposure therapy; thought challenging or cognitive restructuring; or self-monitoring of one's thoughts, emotions, and behaviors. The majority of those that lacked any evidence-based components were mostly distraction tools, such as games, coloring activities, or other audio or visual activities, and more than half included relaxation exercises, which are currently rarely considered therapeutic for anxiety [29]. Evidence on the effectiveness of therapeutic video games was limited and mixed, as confirmed by Barnes and Prescott [28].

Irrespective of their effectiveness or link with evidence-based approaches, young people generally perceive their engagement with these platforms to range from neutral to helpful. Overall, a systematic narrative review of Pretorius et al [36] reported that young people's perception of the helpfulness of web-based resources ranged across the studies-from $80 \%$ of participants in a study indicating that speaking on the web had helped, to $40 \%$ reporting in another study that web-based resources had helped a little, to $59 \%$ reporting in a third study that web-based resources did not make things better or worse.

\section{Factors Associated With Effectiveness and Adherence}

Several systematic reviews and meta-analyses demonstrated that digital mental health interventions with an in-person element (ie, therapist, parent, and peer) were more effective than those that were fully automatized or self-administered.

In another systematic review, Grist et al [42] found a significant effect of therapist support (Cochran $\mathrm{Q}=27.28 ; P<.001$ ) and parental involvement (Cochran $\mathrm{Q}=24.43 ; P<.001$ ). In their analysis, the involvement of a therapist yielded higher effect sizes $(\mathrm{n}=9$; Hedges $g=0.87$; 95\% CI $0.68-1.06 ; P<.001)$ than predominantly self-administered (Hedges $g=0.81 ; 95 \%$ CI -0.68 to $2.31 ; P=.29)$ or purely self-administered interventions (Hedges $g=0.24 ; 95 \%$ CI $0.10-0.38 ; P<.001$ ). Similar findings were also reported by Hollis et al [24].

Garrido et al [35] reported higher pooled effect sizes of digital mental health interventions for depression with supervision than those without supervision (studies with no intervention controls: Cohen $d=0.52$; 95\% CI $0.23-0.80$ and studies with active controls: Cohen $d=0.49 ; 95 \% \mathrm{CI}-0.11$ to 1.01$)$. In a systematic 
review and meta-analysis, Valimaki et al [33] found that web-based interventions with a human element, including face-to-face guidance, monitoring of engagement, or follow-up telephone calls by teachers and health professionals, were more effective than those without a human element.

Grist et al [42] demonstrated a significant difference in effect sizes (Cochran $\mathrm{Q}=9.37 ; P=.002$ ) between trials with ongoing psychological or pharmacological treatment (Hedges $g=0.90$, 95\% CI 0.68-1.11; $P<.001)$ and trials without ongoing treatment (Hedges $g=0.42,95 \%$ CI 0.20-0.63).

In contrast, Harrer et al [34] did not find supervision significantly affecting intervention efficacy; however, this may be because of the multiplicity of the types of interventions included in the review or the older target population (university students). In addition, Ebert et al [39] found no association between parental involvement and better treatment outcomes of cCBT for anxiety or depression in youth (without parental involvement: Hedges $g=0.83$, 95\% CI 0.53-1.13; $P<.001$; $\mathrm{NNT}=2.26$ and with parental involvement: Hedges $g=0.64,95 \%$ CI $0.40-0.88 ; P<.001 ; \mathrm{NNT}=2.86)$.

An in-person element was also associated with adherence and lower dropout rates. Clarke et al [44] suggested that face-to-face or web-based support in web-based interventions was associated with better completion and outcomes. Similarly, Hollis et al [24] reported that human involvement is positively associated with adherence; however, they note that the evidence is scant.

Human contact in digital mental health interventions was also considered useful and valuable by adolescents and young people themselves, in particular, contact with professionals as well as peers with similar experiences and mental health issues [35,37]. Pretorius et al [36] found that young people valued web-based services run by mental health professionals and the opportunity to connect to peers, with $84 \%$ of participants reporting that human contact within a web-based mental health resource is important. In addition, in a systematic review by Ridout and Campbell [37], the involvement of professionals and peers in social networking sites was valued by site users.

Hollis et al [24] reported that adolescents and young people prefer face-to-face mental health interventions over digital interventions. In the Australian sample, two-thirds (59\%) of young people strongly preferred face-to-face treatment, with only $16 \%$ preferring on the web, and in the United Kingdom, half were not interested in CCBT, with preference for face-to-face treatment.

There was some indication that interventions implemented in the school setting were associated with improvements in adolescent mental health knowledge, support seeking, and well-being [44]. School- and web-based interventions were also associated with greater adherence [35,44], and interventions that adolescents and young people completed in their own time were associated with low completion rates and adherence [35].

\section{Design Elements}

Acceptability of interventions was reported to be good $[30,37,40,44]$. Privacy, safety, and discretion were found to be valuable for adolescents and young people [24,30,36]. Related to the stigma associated with mental health issues, adolescents and young people also valued anonymity [24,36]. In this regard, data security, including password protection, control over privacy settings [30], and site moderation by professionals $[36,37]$, were identified as factors influencing the acceptability of digital mental health interventions.

Other characteristics valued by adolescents and young people included the credibility of design, visual appearance, and information and resources provided $[30,35,36]$. The tools and content should be engaging and interactive [30,35]; should provide concise, interesting, and trustworthy information $[24,30,35,36]$; should be esthetically attractive [35,36]; should provide reminders to use [30]; should allow for personalization [30]; should have relatable situations, characters, or avatars [35]; and should reflect local and cultural differences and needs, particularly in terms of minority groups and migrants for social integration. Garrido et al [35] reported that technical glitches were a barrier to complete interventions.

Flexibility, self-reliance, and control were also cited in the reviews as influencing acceptability [24,36]. Adolescents and young people valued in digital mental health interventions the ability to complete interventions on their own terms and pace [24]. According to Pretorius et al [36], 24-hour availability is an important factor, as help-seeking takes place mostly after 11 PM.

\section{Sustainability, Completion, and Adherence}

Most studies included in this review reported only short-term effects on adolescents' mental health. Evidence of long-term effects is limited $[24,33,38-41,44]$. Only one meta-analysis by Valimaki et al [33] with a focus on depression, anxiety, and stress examined the long-term effects of digital health interventions. The study found a statistically significant improvement at the end of the intervention on depressive symptoms $(P=.02$; median $1.68,95 \%$ CI $3.11-0.25)$ and after 6 months $(P=.01$; median $1.78,95 \%$ CI $3.20-0.37)$. The study also found evidence of long-term improvement at 6 months in anxiety symptoms $(P<.001$; median $1.47,95 \%$ CI $2.36-0.59)$ and moods and feelings $(P=.04$; median $5.55,95 \% \mathrm{CI}$ 10.88-0.22), but there was no difference in stress scores.

In terms of cCBT, in line with the standard CBT, effects were higher for interventions of moderate length (1-2 months), for example, on depression at 4-8 weeks (Hedges $g=0.31,95 \%$ CI $0.13-0.49$; NNT=5.75) compared with shorter (Hedges $g=0.09$, $95 \% \mathrm{CI}-0.02$ to $0.21 ; \mathrm{NNT}=20$ ) or longer (Hedges $g=0.13$, $95 \% \mathrm{CI}-0.43$ to $0.69 ; \mathrm{NNT}=13.51)$ programs $(P=.03)$, according to Harrer et al [34]. Although follow-up assessments were rarely reported in studies, Clarke et al [44] also found that improvements after cCBT were maintained at 6 and 12 months.

In addition to limited evidence of the long-term effects of digital mental health interventions, Hollis et al [24] found limited evidence of a dose-response (ie, how much of the intervention is needed to produce beneficial outcomes).

Overall, dropout was found to be high in the systematic reviews and meta-analyses of studies on digital mental health interventions. Completion rates ranged greatly from $10 \%$ to $94 \%$ in a study by Valimaki et al [33] and from $65 \%$ to $83 \%$ 
among app users in a study by Grist et al [30], and completion rates were approximately half on average in a study by Clarke et al [44]. However, data on dropout and adherence were generally considered weak in the original review samples, with only a limited number of studies reporting data on adherence [24,30,33,35,36,44].

Gender was considered as a predictor of adherence. According to Garrido et al [35], females were more likely to complete the intervention than males [35]. In addition, mental health status was associated with completion, and higher completion was predicted for adolescents and young people with higher depression scores at the baseline [35,44], a longer history of mood disorders, or low anxiety scores at pretest [36]. Furthermore, according to Pretorius et al [36], high levels of psychological distress were associated with help-seeking on the web.

\section{Cost-Effectiveness}

Data on cost-effectiveness were not reported in any of the systematic reviews and meta-analyses in our sample, and there was no indication of research and development costs. A total of 5 systematic reviews noted that despite being widely considered low cost, for example, because of reduced time and personnel expenses [43], there is still a lack of data on the cost-effectiveness and economic benefits of digital mental health interventions [24,29,32,33,42].

\section{Generalizability of Findings}

None of the studies reported on the socioeconomic background or other characteristics of the target populations. Most studies were conducted in high-income countries across Europe $(n=71)$ and in the United States $(n=21)$, Australia $(n=21)$, Canada $(n=13)$, and New Zealand $(n=9)$. In terms of low- and middle-income economies, interventions were reported only from 4 countries, with most studies conducted in China $(n=9)$, including Hong Kong, and, to a lesser extent, in Chile $(\mathrm{n}=2)$, Egypt $(n=1)$, and Thailand $(n=1)$. Given the homogeneity of the country contexts and lack of analysis of the characteristics of the target population, the generalizability of the findings is limited beyond adolescents and young people in high-income country settings.

\section{Discussion}

\section{Principal Findings}

We explored 18 reviews and meta-analyses on the effectiveness of digital mental health interventions for adolescents and young people. On the basis of this systematic overview, we found evidence on the effectiveness of cCBT on anxiety and depression, whereas the effectiveness of other digital mental health interventions, including therapeutic video games, mobile apps, or social networking sites, remains inconclusive. The effects vary based on a targeted set of symptoms, with evidence of effectiveness found on anxiety; depression; and, to a lesser extent, stress, and based on age, with older participants gaining greater benefits compared with younger adolescent participants.

Digital interventions that deploy evidence-based treatment such as cCBT are generally comparable with face-to-face care.
Importantly, in-person elements (eg, professional, peer, or parent engagement) were found to strengthen the effectiveness of digital interventions. In addition, digital interventions improved outcomes relative to waitlist controls, suggesting that they may have additional benefits for supporting adolescents and young people in cases where access to care is limited or wait times to access are long.

Furthermore, although young people report a range of neutral to positive attitudes about the helpfulness of digital platforms for mental health support, few studies have tracked the long-term outcomes of digital mental health interventions. Although acceptability is considered good, dropout is common, and adherence is relatively weak if not boosted by in-person elements. Very little is known about cost-effectiveness, with no systematic reviews or meta-analyses reporting on cost-effectiveness. Finally, given that the vast majority of interventions are implemented in high-income countries, very little is known about the generalizability of the findings to lowand middle-income countries and to a range of adolescents and young people with different socioeconomic, cultural, racial, or other backgrounds.

Despite some converging evidence across meta-analyses and reviews, research in this area appears to have consistently low quality and rigor as per assessment using the AMSTAR 2 criteria. The primary constraints for this were that the articles analyzed reported many limitations in their samples. These included a small number of studies meeting the inclusion criteria $[28,30,31,38,39,41,44]$, weak quality of studies $[32,34,40,41,43,44]$, and the heterogeneity across the interventions in terms of content and delivery [24,31,34,36,39-41,44]. Furthermore, study participants were often recruited by self-selection [30,37,44], sample sizes were small [24,30,32], and blinding was limited [24,30,35]. Notably, one systematic review by Grist et al [30] also pointed out that almost all studies were either undertaken or supported by the program developer, which may greatly affect the study design and interpretation of the findings.

\section{Comparison With Previous Work}

With the growing application of digital technologies in public health, digital health interventions are perceived to increase access to health services and information, self-care, and empowerment and reduce the cost and burden on health systems [45]. In this context, as digital natives, adolescents and young people are considered as early adopters of technology [46], with the potential to benefit from digital health technologies, including for mental health.

Although there is an increasing body of research on the effectiveness of digital mental health technologies targeting adolescents and young people, most focus on evaluating cCBT. In line with our findings, cCBT for addressing anxiety and depression in adolescents and young people has been found to be effective, including in school-based prevention and early identification studies and in family-based studies [47]. The effectiveness of cCBT in the adult population has also been established [48,49]. Given that face-to-face CBT is widely used as a treatment for depressive symptoms and disorders in this age group [50], with evidence of its effectiveness found in a 
number of systematic reviews [51-53], it is plausible that it also works in a standardized digital format.

Beyond the cCBT, evidence on the effectiveness of other digital mental health interventions, including therapeutic video games, mobile apps, and social networking sites, was extremely limited. Although these may have the potential to engage adolescents and young people and thus support traditional face-to-face treatment [54] and although social network sites, including gaming elements, are found to be promising in promoting changes in health-related behaviors $[55,56]$, the quality of content and expected outcomes vary [57].

Similar to our findings, studies have reported low adherence and high dropout rates in adolescents and young people using digital mental health interventions [58-60], although there are also contrasting data with high levels of acceptability and usability [47], including from low- and middle-income countries [61-63]. However, the contrasting data are mainly reported in feasibility studies, based on adolescents without mental health conditions, and thus, the data may not be applicable for adolescents and young people with mental health issues.

Furthermore, to some extent, the cost-effectiveness of digital health interventions has been studied in the general population and other areas of health, including the management of cardiovascular diseases [64] and insomnia [65]. However, there is a lack of assessment of cost-effectiveness in digital mental health interventions overall and for adolescents and young people in particular. This may be because of methodological limitations related to a number of studies, including heterogeneity of interventions and outcomes that hinder the overall assessment of effectiveness.

Finally, despite an increasing share of young population and users of digital technology in low- and middle-income countries, very little research has been conducted in these settings $[61,62]$. In line with our findings, the generalizability to low- and middle-income countries [47,66] as well as adolescents and young people with different backgrounds [47] is noted by previous research. However, good-quality research on cost-effectiveness and generalizability is critical when scaling up these interventions in settings with already limited resources for health care, including mental health services.

\section{Limitations}

Although this overview of meta-analyses and systematic reviews provides a broad assessment of the results and quality of digital mental health intervention research focused on adolescents and young people, several limitations are evident. In this overview, we have provided a higher-level synthesis of previous systematic reviews in this area, covering a range of digital health interventions and expected health outcomes. Although this is a critical step in assessing the value of digital interventions overall, it introduces some challenges for interpretation (eg, variation in study settings, methods, and comparators, with inconsistencies in reporting within and across the reviews, including the level of description of primary studies and the findings). However, these inconsistencies highlight an important need for more systematic approaches to testing and reporting on effectiveness across studies. Inclusion criteria for some of the studies reviewed here may have resulted in overlap of primary studies between the reviews. In addition, as the field of digital interventions is fast-moving, many of the interventions tested may now be outdated or defunct. However, cross-study heterogeneity is why this review is needed to identify converging effects that emerge, despite variation in specific tests across studies and reviews.

Finally, we included only published peer-reviewed systematic reviews and meta-analyses in the English language. Inclusion of randomized control trials and other original research, including in other languages, may have yielded more studies focused on low- and middle-income countries.

Despite these limitations, the present overview provides a broad picture of the converging evidence supporting the promise of digital mental health interventions in adolescents and young people and highlights a critical need for the field to increase the number of high-quality effectiveness trials to ensure that the interest and enthusiasm in these approaches do not outpace their results.

\section{Conclusions}

This overview of meta-analyses and systematic reviews suggests that digital mental health interventions for adolescents and young people have modest positive effects, especially when relying on evidence-based treatment content or in-person elements that boost engagement. Their potential for settings with limited resources for health and cost savings compared with traditional treatment remains understudied. Therefore, when developing, investing in, and delivering digital mental health programs for adolescents and young people, we need to better consider what types of services are meaningful to be provided through a digital platform (ie, cCBT that deploys the same techniques as face-to-face therapy and is typically delivered by a professional), for what outcomes (eg, self-reported vs diagnosed and mild vs severe symptoms), what type of services adolescents and young people themselves prefer (standard vs digital), and to what extent these are cost-saving and clinically effective across a variety of settings with different resources (ie, in high- vs low-resource settings).

\section{Acknowledgments}

This work was supported by the Fondation Botnar, Basel, Switzerland. The authors thank Silvia Minozzi and David A Ross for their advice on the structure and content of this review.

\section{Authors' Contributions}

SL contributed to conceptualizing and designing the study; conducted literature search, quality assessment, analysis, and data interpretation; drafted the initial manuscript; and reviewed and revised the manuscript. KTF contributed to advancing the ideas, 
aided with analytic interpretation, and reviewed and revised the manuscript. JM contributed to the literature search, quality assessment, data extraction, analysis, and review of the manuscript. BW contributed to conceptualizing and designing the study. NS contributed to conceptualizing and designing the study, conducted analysis and data interpretation, drafted the initial manuscript, and reviewed and revised the manuscript. SL and NS are joint first authors of the review.

\section{Conflicts of Interest}

None declared.

\section{References}

1. WHO. Adolescent Mental Health. Fact Sheet. URL: https://www.who.int/news-room/fact-sheets/detail/ adolescent-mental-health [accessed 2020-07-28]

2. Patton GC, Sawyer SM, Santelli JS, Ross DA, Afifi R, Allen NB, et al. Our future: a Lancet commission on adolescent health and wellbeing. Lancet 2016 Jun 11;387(10036):2423-2478. [doi: 10.1016/S0140-6736(16)00579-1] [Medline: 27174304]

3. WHO. Adolescent mental health. Published October 23. 2019. URL: https://www.who.int/news-room/fact-sheets/detail/ adolescent-mental-health [accessed 2020-06-08]

4. UNICEF. Adolescent mental health. Published August. 2019. URL: https://data.unicef.org/topic/child-health/mental-health/ [accessed 2020-06-08]

5. WHO. Suicides by age and income level. Published. 2016. URL: https://www.who.int/mental health/prevention/suicide/ suicideprevent/en/ [accessed 2020-06-08]

6. WHO. Causes of Death among Adolescents. Global Health Estimates (GHE). WHO. 2016. URL: https://www.who.int/ healthinfo/global burden disease/estimates/en/ [accessed 2020-07-06] [WebCite Cache ID

https://www.who.int/healthinfo/global burden disease/estimates/en/]

7. UNICEF. Growing up in a Connected World. UNICEF Office of Research ? Innocenti. 2019. URL: https://www. unicef-irc.org/publications/1060-growing-up-in-a-connected-world.html [accessed 2020-06-09]

8. $\quad$ UNICEF. Children in a Digital World. In: The State of the World's Children. New York: UNICEF; 2017.

9. International TU, World TDR. Mobile cellular subscriptions; individuals using the Internet. Published. 2018. URL: https:/ /data.worldbank.org/indicator/IT.CEL.SETS.P2 [accessed 2020-07-28]

10. Israni ST, Matheny ME, Matlow R, Whicher D. Equity, Inclusivity, and Innovative Digital Technologies to Improve Adolescent and Young Adult Health. J Adolesc Health 2020 Aug;67(2S):S4-S6 [FREE Full text] [doi: 10.1016/j.jadohealth.2020.05.014] [Medline: $\underline{\text { 32718514] }}$

11. Webb L, Clary LK, Johnson RM, Mendelson T. Electronic and School Bullying Victimization by Race/Ethnicity and Sexual Minority Status in a Nationally Representative Adolescent Sample. J Adolesc Health 2020 Jul 10:378-384. [doi: 10.1016/j.jadohealth.2020.05.042] [Medline: 32654837]

12. Moreno MA, Kerr BR, Jenkins M, Lam E, Malik FS. Perspectives on Smartphone Ownership and Use by Early Adolescents. J Adolesc Health 2019 Apr;64(4):437-442. [doi: 10.1016/j.jadohealth.2018.08.017] [Medline: 30389204]

13. Giovanelli A, Ozer EM, Dahl RE. Leveraging Technology to Improve Health in Adolescence: A Developmental Science Perspective. J Adolesc Health 2020 Aug;67(2S):S7-S13 [FREE Full text] [doi: 10.1016/j.jadohealth.2020.02.020] [Medline: $\underline{32718517]}$

14. Aschbrenner KA, Naslund JA, Tomlinson EF, Kinney A, Pratt SI, Brunette MF. Adolescents' Use of Digital Technologies and Preferences for Mobile Health Coaching in Public Mental Health Settings. Front Public Health 2019;7:178 [FREE Full text] [doi: 10.3389/fpubh.2019.00178] [Medline: 31312629]

15. Naslund JA, Aschbrenner KA, McHugo GJ, Unützer J, Marsch LA, Bartels SJ. Exploring opportunities to support mental health care using social media: A survey of social media users with mental illness. Early Interv Psychiatry 2017 Oct 20;13(3):405-413. [doi: 10.1111/eip.12496] [Medline: 29052947]

16. Shortliffe EH. Digital Medicine and Biomedical Informatics: What's in a Name? Methods Inf Med 2016 Oct 17;55(5):389-391. [doi: 10.3414/ME15-22-0005] [Medline: 27524308]

17. Kaushik A, Kostaki E, Kyriakopoulos M. The stigma of mental illness in children and adolescents: A systematic review. Psychiatry Res 2016 Sep 30;243:469-494. [doi: 10.1016/j.psychres.2016.04.042] [Medline: 27517643]

18. Grist R, Porter J, Stallard P. Mental Health Mobile Apps for Preadolescents and Adolescents: A Systematic Review. J Med Internet Res 2017 May 25;19(5):e176 [FREE Full text] [doi: 10.2196/jmir.7332] [Medline: 28546138]

19. WHO. Health for the World's Adolescents: A Second Chance in the Second Decade. Geneva: WHO; 2014:A.

20. Sawyer SM, Azzopardi PS, Wickremarathne D, Patton GC. The age of adolescence. Lancet Child Adolesc Health 2018 Mar;2(3):223-228. [doi: 10.1016/S2352-4642(18)30022-1] [Medline: $\underline{30169257]}$

21. WHO. Mental Disorders. WHO. 2019. URL: https://www.who.int/en/news-room/fact-sheets/detail/mental-disorders [accessed 2020-10-02]

22. WHO. Universal Health Coverage for Mental Health. Geneva: WHO; 2019.

23. Lenhard F, Andersson E, Mataix-Cols D, Rück C, Vigerland S, Högström J, et al. Therapist-Guided, Internet-Delivered Cognitive-Behavioral Therapy for Adolescents With Obsessive-Compulsive Disorder: A Randomized Controlled Trial. J 
Am Acad Child Adolesc Psychiatry 2017 Jan;56(1):10-19.e2 [FREE Full text] [doi: 10.1016/j.jaac.2016.09.515] [Medline: 27993223]

24. Hollis C, Falconer CJ, Martin JL, Whittington C, Stockton S, Glazebrook C, et al. Annual Research Review: Digital health interventions for children and young people with mental health problems: a systematic and meta-review. J Child Psychol Psychiatry 2017;58(4):474-503. [doi: 10.1111/jepp.12663] [Medline: 27943285]

25. Merriam-Webster CD. Cognitive Behavioural Therapy, CBT. 2020. URL: https://www.merriam-webster.com/dictionary/ cognitive\%20behavioral\%20therapy [accessed 2020-09-02]

26. Karlsson P, Bergmark A. Compared with what? An analysis of control-group types in Cochrane and Campbell reviews of psychosocial treatment efficacy with substance use disorders. Addiction 2015 Jan 15;110(3):420-428. [doi: 10.1111/add.12799]

27. Shea BJ, Reeves BC, Wells G, Thuku M, Hamel C, Moran J, et al. AMSTAR 2: a critical appraisal tool for systematic reviews that include randomised or non-randomised studies of healthcare interventions, or both. BMJ 2017 Dec 21;358:j4008 [FREE Full text] [doi: 10.1136/bmj.j4008] [Medline: 28935701]

28. Barnes S, Prescott J. Empirical Evidence for the Outcomes of Therapeutic Video Games for Adolescents With Anxiety Disorders: Systematic Review. JMIR Serious Games 2018 Feb 28;6(1):e3 [FREE Full text] [doi: 10.2196/games.9530] [Medline: 29490893]

29. Bry LJ, Chou T, Miguel E, Comer JS. Consumer Smartphone Apps Marketed for Child and Adolescent Anxiety: A Systematic Review and Content Analysis. Behav Ther 2018 Dec;49(2):249-261. [doi: 10.1016/j.beth.2017.07.008] [Medline: 29530263]

30. Grist R, Porter J, Stallard P. Mental Health Mobile Apps for Preadolescents and Adolescents: A Systematic Review. J Med Internet Res 2017 May 25;19(5):e176 [FREE Full text] [doi: 10.2196/jmir.7332] [Medline: 28546138]

31. Davies EB, Morriss R, Glazebrook C. Computer-delivered and web-based interventions to improve depression, anxiety, and psychological well-being of university students: a systematic review and meta-analysis. J Med Internet Res 2014;16(5):e130 [FREE Full text] [doi: 10.2196/jmir.3142] [Medline: 24836465]

32. Farrer L, Gulliver A, Chan JKY, Batterham PJ, Reynolds J, Calear A, et al. Technology-based interventions for mental health in tertiary students: systematic review. J Med Internet Res 2013;15(5):e101 [FREE Full text] [doi: 10.2196/jmir.2639] [Medline: 23711740]

33. Välimäki M, Anttila K, Anttila M, Lahti M. Web-Based Interventions Supporting Adolescents and Young People With Depressive Symptoms: Systematic Review and Meta-Analysis. JMIR Mhealth Uhealth 2017 Dec 08;5(12):e180 [FREE Full text] [doi: 10.2196/mhealth.8624] [Medline: 29222079]

34. Harrer M, Adam SH, Baumeister H, Cuijpers P, Karyotaki E, Auerbach RP, et al. Internet interventions for mental health in university students: A systematic review and meta-analysis. Int J Methods Psychiatr Res 2019 Jun;28(2):e1759. [doi: 10.1002/mpr.1759] [Medline: $\underline{\text { 30585363] }}$

35. Garrido S, Millington C, Cheers D, Boydell K, Schubert E, Meade T, et al. What Works and What Doesn't Work? A Systematic Review of Digital Mental Health Interventions for Depression and Anxiety in Young People. Front Psychiatry 2019;10:759 [FREE Full text] [doi: 10.3389/fpsyt.2019.00759] [Medline: 31798468]

36. Pretorius C, Chambers D, Coyle D. Young People's Online Help-Seeking and Mental Health Difficulties: Systematic Narrative Review. J Med Internet Res 2019 Nov 19;21(11):e13873 [FREE Full text] [doi: 10.2196/13873] [Medline: $\underline{31742562]}$

37. Ridout B, Campbell A. The Use of Social Networking Sites in Mental Health Interventions for Young People: Systematic Review. J Med Internet Res 2018 Dec 18;20(12):e12244 [FREE Full text] [doi: 10.2196/12244] [Medline: 30563811]

38. Podina IR, Mogoase C, David D, Szentagotai A, Dobrean A. A Meta-Analysis on the Efficacy of Technology Mediated CBT for Anxious Children and Adolescents. J Rat-Emo Cognitive-Behav Ther 2015 Nov 17;34(1):31-50. [doi: 10.1007/s10942-015-0228-5]

39. Ebert DD, Zarski A, Christensen H, Stikkelbroek Y, Cuijpers P, Berking M, et al. Internet and computer-based cognitive behavioral therapy for anxiety and depression in youth: a meta-analysis of randomized controlled outcome trials. PLoS One 2015;10(3):e0119895 [FREE Full text] [doi: 10.1371/journal.pone.0119895] [Medline: 25786025]

40. Pennant ME, Loucas CE, Whittington C, Creswell C, Fonagy P, Fuggle P, et al. Computerised therapies for anxiety and depression in children and young people: a systematic review and meta-analysis. Behav Res Ther 2015 Apr;67:1-18. [doi: 10.1016/j.brat.2015.01.009] [Medline: 25727678]

41. Ye X, Bapuji SB, Winters SE, Struthers A, Raynard M, Metge C, et al. Effectiveness of internet-based interventions for children, youth, and young adults with anxiety and/or depression: a systematic review and meta-analysis. BMC Health Serv Res 2014 Jul 18;14:313 [FREE Full text] [doi: 10.1186/1472-6963-14-313] [Medline: 25037951]

42. Grist R, Croker A, Denne M, Stallard P. Technology Delivered Interventions for Depression and Anxiety in Children and Adolescents: A Systematic Review and Meta-analysis. Clin Child Fam Psychol Rev 2019 Jun;22(2):147-171 [FREE Full text] [doi: 10.1007/s10567-018-0271-8] [Medline: 30229343]

43. Vigerland S, Lenhard F, Bonnert M, Lalouni M, Hedman E, Ahlen J, et al. Internet-delivered cognitive behavior therapy for children and adolescents: A systematic review and meta-analysis. Clin Psychol Rev 2016 Dec;50:1-10 [FREE Full text] [doi: 10.1016/j.cpr.2016.09.005] [Medline: 27668988] 
44. Clarke AM, Kuosmanen T, Barry MM. A systematic review of online youth mental health promotion and prevention interventions. J Youth Adolesc 2015 Jan;44(1):90-113. [doi: 10.1007/s10964-014-0165-0] [Medline: 25115460]

45. WHO. WHO Guideline: Recommendations on Digital Interventions for Health System Strengthening. Geneva: WHO; 2019.

46. Giovanelli A, Ozer EM, Dahl RE. Leveraging Technology to Improve Health in Adolescence: A Developmental Science Perspective. J Adolesc Health 2020 Aug;67(2S):S7-S13 [FREE Full text] [doi: 10.1016/j.jadohealth.2020.02.020] [Medline: 32718517]

47. Das JK, Salam RA, Lassi ZS, Khan MN, Mahmood W, Patel V, et al. Interventions for Adolescent Mental Health: An Overview of Systematic Reviews. Journal of Adolescent Health 2016 Oct;59(4):S49-S60. [doi: 10.1016/j.jadohealth.2016.06.020]

48. Adelman CB, Panza KE, Bartley CA, Bontempo A, Bloch MH. A meta-analysis of computerized cognitive-behavioral therapy for the treatment of DSM-5 anxiety disorders. J Clin Psychiatry 2014 Jul;75(7):e695-e704. [doi: 10.4088/JCP.13r08894] [Medline: 25093485]

49. Andrews G, Basu A, Cuijpers P, Craske M, McEvoy P, English C, et al. Computer therapy for the anxiety and depression disorders is effective, acceptable and practical health care: An updated meta-analysis. Journal of Anxiety Disorders 2018 Apr;55:70-78. [doi: 10.1016/j.janxdis.2018.01.001]

50. Oud M, de Winter L, Vermeulen-Smit E, Bodden D, Nauta M, Stone L, et al. Effectiveness of CBT for children and adolescents with depression: A systematic review and meta-regression analysis. Eur. psychiatr 2019 Jan 16;57:33-45. [doi: 10.1016/j.eurpsy.2018.12.008]

51. Sigurvinsdóttir AL, Jensínudóttir KB, Baldvinsdóttir KD, Smárason O, Skarphedinsson G. Effectiveness of cognitive behavioral therapy (CBT) for child and adolescent anxiety disorders across different CBT modalities and comparisons: a systematic review and meta-analysis. Nordic Journal of Psychiatry 2019 Nov 18;74(3):168-180. [doi: $\underline{10.1080 / 08039488.2019 .1686653}$

52. Viswanathan M, Kennedy S, McKeeman J, Christian R. Treatment of Depression in Children and Adolescents. A Systematic Review. AHRQ Comparative Effectiveness Reviews. Report No.EHC005-EF. Rockville, MD: Agency for Healthcare Research and Quality; 2020.

53. Treatment of Anxiety Disorders. A Systematic Review. SBU Yellow Report No. 171/1+2. Stockholm: Swedish Council on Health Technology Assessment; 2005.

54. Al Husni AKM, Delvenne V. Use of Video Games in a Child And Adolescent Psychiatric Unit. Psychiatr Danub. 167AD;32(Suppl 1) 2020:167-167. [Medline: 32890384]

55. Laranjo L, Arguel A, Neves AL, Gallagher AM, Kaplan R, Mortimer N, et al. The influence of social networking sites on health behavior change: a systematic review and meta-analysis. J Am Med Inform Assoc 2015 Jan;22(1):243-256. [doi: 10.1136/amiajnl-2014-002841] [Medline: 25005606]

56. Chau MM, Burgermaster M, Mamykina L. The use of social media in nutrition interventions for adolescents and young adults_A systematic review. International Journal of Medical Informatics 2018 Dec;120:77-91. [doi: 10.1016/j.ijmedinf.2018.10.001]

57. Korda H, Itani Z. Harnessing social media for health promotion and behavior change. Health Promot Pract 2013 Jan;14(1):15-23. [doi: 10.1177/1524839911405850] [Medline: 21558472]

58. Achilles MR, Anderson M, Li SH, Subotic-Kerry M, Parker B, O’Dea B. Adherence to e-mental health among youth: Considerations for intervention development and research design. DIGITAL HEALTH 2020 May 21;6:205520762092606. [doi: 10.1177/2055207620926064]

59. Liverpool S, Mota CP, Sales CMD, Čuš A, Carletto S, Hancheva C, et al. Engaging Children and Young People in Digital Mental Health Interventions: Systematic Review of Modes of Delivery, Facilitators, and Barriers. J Med Internet Res 2020 Jun 23;22(6):e16317. [doi: 10.2196/16317]

60. Lillevoll KR, Vangberg HCB, Griffiths KM, Waterloo K, Eisemann MR. Uptake and adherence of a self-directed internet-based mental health intervention with tailored e-mail reminders in senior high schools in Norway. BMC Psychiatry 2014;14(1):14. [doi: 10.1186/1471-244X-14-14]

61. Sobowale K, Nguyen M, Weiss B, Van TTH, Trung LT. Acceptability of internet interventions for youth mental health in Vietnam. Glob. Ment. Health 2016 Jul 14;14(3):e22. [doi: 10.1017/gmh.2016.18]

62. Kanuri N, Arora P, Talluru S, Colaco B, Dutta R, Rawat A, et al. Examining the initial usability, acceptability and feasibility of a digital mental health intervention for college students in India. Int J Psychol 2019 Dec 22;55(4):657-673. [doi: 10.1002/ijop.12640]

63. Maloney CA, Abel WD, McLeod HJ. Jamaican adolescents' receptiveness to digital mental health services: A cross-sectional survey from rural and urban communities. Internet Interventions $2020 \mathrm{Sep} ; 21$ (Sept 21):100325. [doi: 10.1016/j.invent.2020.100325]

64. Jiang X, Ming W, You JH. The Cost-Effectiveness of Digital Health Interventions on the Management of Cardiovascular Diseases: Systematic Review. J Med Internet Res 2019 Jun 17;21(6):e13166. [doi: 10.2196/13166]

65. Darden M, Espie C, Carl J, Henry A. Cost-effectiveness of digital CBT (Sleepio) for insomnia: A Markov simulation model in the United States. Sleep 2020:zsaa223. [doi: 10.1093/sleep/zsaa223] 
66. Abaza H, Marschollek M. mHealth Application Areas and Technology Combinations. A Comparison of Literature from High and Low/Middle Income Countries. Methods Inf Med 2017 Aug 08;56(7):e105-e122. [doi: 10.3414/ME17-05-0003] [Medline: 28925418]
Abbreviations
ADHD: attention-deficit/hyperactivity disorder
AMSTAR 2: A Measurement Tool to Assess Systematic Reviews
CBT: cognitive behavioral therapy
cCBT: computerized cognitive behavioral therapy
NNT: number needed to treat
SMD: standardized mean difference

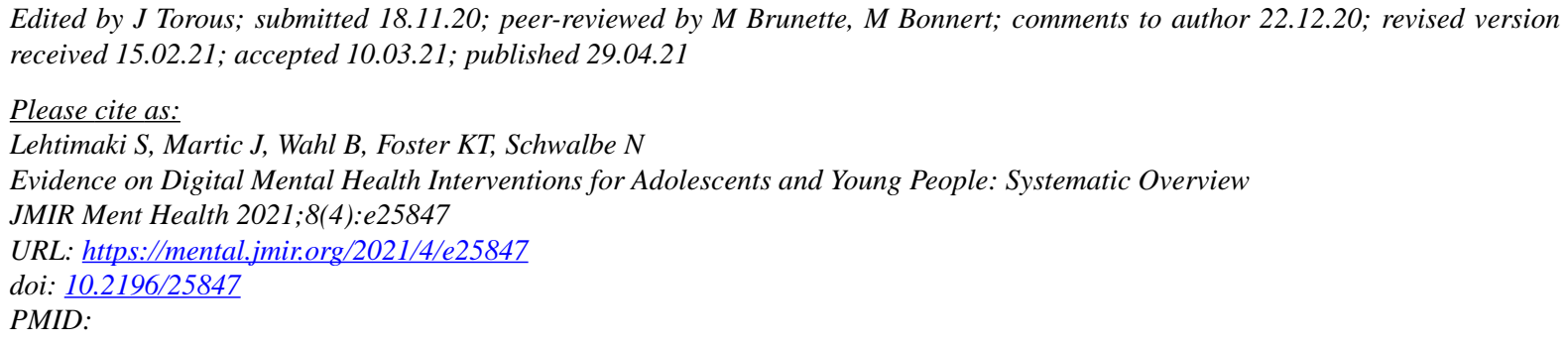

(C) Susanna Lehtimaki, Jana Martic, Brian Wahl, Katherine T Foster, Nina Schwalbe. Originally published in JMIR Mental Health (https://mental.jmir.org), 29.04.2021. This is an open-access article distributed under the terms of the Creative Commons Attribution License (https://creativecommons.org/licenses/by/4.0/), which permits unrestricted use, distribution, and reproduction in any medium, provided the original work, first published in JMIR Mental Health, is properly cited. The complete bibliographic information, a link to the original publication on http://mental.jmir.org/, as well as this copyright and license information must be included. 